\title{
Neuronal migration and its disorders affecting the CA3 region
}

\author{
Richard Belvindrah ${ }^{1,2,3}$, Marika Nosten-Bertrand ${ }^{1,2,3}$ and Fiona Francis ${ }^{1,2,3 *}$ \\ 1 INSERM UMR-S 839, Paris, France \\ ${ }^{2}$ Sorbonne Universités, Université Pierre et Marie Curie, Univ Paris 06, Paris, France \\ ${ }^{3}$ Institut du Fer à Moulin, Paris, France
}

\section{Edited by:}

Richard Miles, Institut pour le

Cerveau et la Moëlle Epinière,

France

Reviewed by:

Alfonso Represa, INMED, France

Michael Frotscher, University

Medical Center Hamburg-

Eppendorf, Germany

Scott C. Baraban, University of

California, San Francisco, USA

${ }^{*}$ Correspondence:

Fiona Francis, Institut du Fer à

Moulin, INSERM UMR-S 839,

17 Rue du Fer à Moulin,

75005 Paris, France

e-mail: fiona.francis@inserm.fr
In this review, we focus on CA3 neuronal migration disorders in the rodent. We begin by introducing the main steps of hippocampal development, and we summarize characteristic hippocampal malformations in human. We then describe various mouse mutants showing structural hippocampal defects. Notably, genes identified in human cortical neuronal migration disorders consistently give rise to a CA3 phenotype when mutated in the mouse. We successively describe their molecular, physiological and behavioral phenotypes that together contribute to a better understanding of CA3-dependent functions. We finally discuss potential factors underlying the CA3 vulnerability revealed by these mouse mutants and that may also contribute to other human neurological and psychiatric disorders.

Keywords: neurodevelopment, mouse mutant, epilepsy, lamination, hippocampus

\section{BASIC STEPS OF HIPPOCAMPAL DEVELOPMENT}

The development of the rodent hippocampus in the medial telencephalon starts in mid-embryogenesis, as factors are secreted from the cortical hem to induce, specify and amplify the adjacent neuroepithelium to produce cortical tissue (Hoch et al., 2009; Pierani and Wassef, 2009; Subramanian and Tole, 2009; Subramanian et al., 2009). Hippocampal Cajal Retzius cells are also derived from the cortical hem and required for correct hippocampal organization (Bielle et al., 2005; Chizhikov et al., 2010; reviewed in Khalaf-Nazzal and Francis, 2013). The hippocampus shares a neuroepithelium which extends dorsally to ventrally through neocortical, subicular, hippocampal and septal regions. During hippocampal pyramidal cell neurogenesis, progenitor cells in these neuroepithelial ventricular zones (VZs) divide to produce neurons, which migrate radially toward the pial surface. Specialized progenitors are radial glial cells which have their somata in the VZ, a short apical process descending to the ventricular lining and a long basal process extending up to the pial surface (Nowakowski and Rakic, 1979; Seri et al., 2001). Cajal-Retzius cells in the marginal zone (MZ) play a critical role during development, initially secreting factors, which help maintain radial glial cell morphology and attachment to the pial surface (Zhao et al., 2004).

As shown extensively in the neocortex, radial glial cells can divide either symmetrically or asymmetrically, producing other progenitor cells (basal progenitors) and neurons (reviewed by Götz and Huttner, 2005; Kriegstein et al., 2006). In earlier stages of development, neurons may migrate by somal translocation, moving their nuclei within a long basal process attached to the pial surface (Nadarajah and Parnavelas, 2002). As shown firstly by classical neuroanatomical methods and later by videomicroscopy, radial glial cell processes later serve as guides for migrating neurons (radial glial guided locomotion). A variety of molecules, both intracellular and extracellular, have been shown to influence this mode of migration (see section Mouse Mutants and Molecular Mechanisms Important for Migration and Lamination). Neurons detach from these guides to settle in the cortical plate in a characteristic inside-out lamination pattern (reviewed by Gupta et al., 2002). Somal translocation may also play a role at these end stages of migration. Different waves of migration correspond to neurons born at different timepoints of neurogenesis. Earlier-born neurons settle in the deeper neocortical layers, whilst later born neurons cross through these layers to reach more superficial regions. The exact mechanisms regulating pyramidal neuron detachment from radial glial processes are unclear, although the reelin protein (see section Mouse Mutants and Molecular Mechanisms Important for Migration and Lamination), secreted by Cajal-Retzius cells, may play an instrumental role (Franco et al., 2011). Detached neurons then continue to differentiate, growing their apical and basal dendrites, and long axons.

Development occurs similarly in the hippocampus. As characterized in detail by Altman and Bayer in the rat dorsal hippocampus (Altman and Bayer, 1990a), using radioactive thymidine to label cells at different ages, radial glial progenitor cells in the convex-shaped ammonic neuroepithelium show a high level of proliferative activity and cycle their nuclei spatially within the $\mathrm{VZ}$ in a process termed interkinetic nuclear migration. Waves of migrating cells born at different time-points have also been characterized, however distinct inside-out lamination in the compact hippocampal plate is less well recognized (Altman and Bayer, 1990a; Fleck et al., 2000; Tole and Grove, 2001; Nakahira and Yuasa, 2005). A majority of pyramidal neurons are generated 
between E16 and E20 in the rat hippocampus. By E20/E21 there are many fewer cells proliferating in the ammonic neuroepithelium. Migrating neurons in the hippocampal intermediate zone (IZ) were recognized as scattered spindle-shaped cells distinguishable from periventricular mitotic cells. In a second paper by the same authors (Altman and Bayer, 1990b), migrating cells were found to organize in bands, one more compact closer to the neuroepithelium and one more diffuse closer to the forming pyramidal cell layer. Cells were found to settle in the pyramidal cell layer (or hippocampal plate) 3-5 days after leaving the neuroepithelium (Figure 1), after a pause period, which the authors termed "sojourning." Sojourning has been proposed to allow pyramidal neurons to begin to polarize and to initiate axon growth which may occur far from the hippocampal plate (Altman and Bayer, 1990b). As post-mitotic neurons leave the VZs, they first take on a transient "multipolar" morphology, moving small distances laterally in the sub-VZ, whilst potentially waiting for appropriate signals which will induce them to acquire a bi-polar morphology with a leading and trailing process, perpendicularly oriented with respect to the ventricular lining. These morphological changes have been nicely characterized using the technique of in utero electroporation to label isolated cells focally with a fluorescent marker (Nakahira and Yuasa, 2005; Navarro-Quiroga et al., 2007).

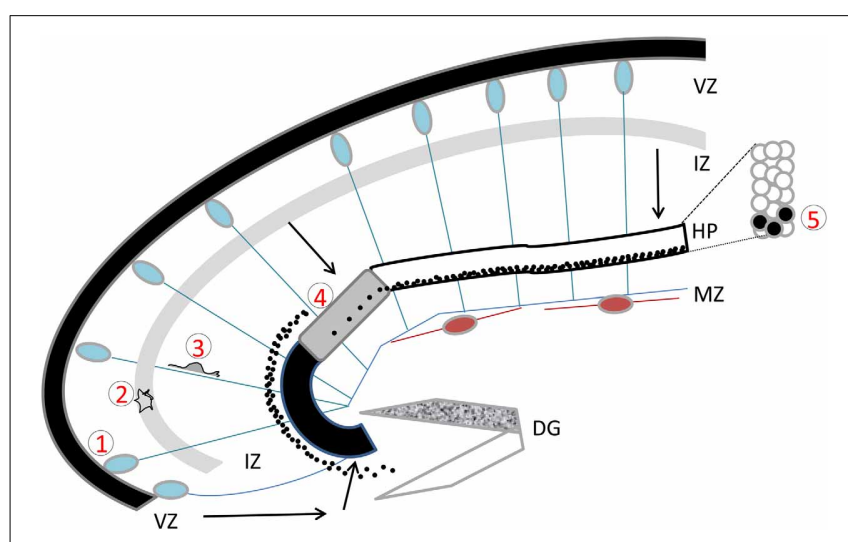

FIGURE 1 | The developing hippocampus. Radial glial cells are represented with their somata in the ventricular zone (VZ) and long basal processes extending up to the marginal zone (MZ). These processes serve as guides for migration. Cajal Retzius cells are schematized in brown. Migration pathways across the intermediate zone (IZ) are indicated by arrows. The hippocampal plate (HP) is shown in white, gray, and black to indicate the CA1, CA2, and CA3 fields respectively. The dentate gyrus (DG) is indicated as a V-shaped structure, at this stage the inferior blade (shown in white) is not completely formed, whereas the superior blade (shown in mottled gray) is taking shape. A BrdU injection at E18 in the rat, with sacrifice 4 days later reveals BrdU-labeled cells as schematized by the black dots: cells born at E18 have already reached the CA1 developing pyramidal cell layer, whereas CA3 cells are still found in the IZ, requiring another full day to cross the CA3 pyramidal cell layer. An inset shows the organization of somata in the pyramidal cell layer. Five successive steps of development are indicated, (1) cell proliferation and neurogenesis in the VZ; (2) a multipolar phase above the $\mathrm{VZ}$; (3) a bipolar phase of migration through the IZ; (4) insertion in the hippocampal plate; (5) settling in the appropriate layer. Schema based on data shown in Altman and Bayer (1990b), Figure 3.
Nowakowski and Rakic (1979), studying migration in the fetal monkey hippocampus, also extensively characterized this radial-glial guided migration, but no mention was made of other migration modes. Even concerning the end stages of migration, as cells reached the hippocampal plate, although these authors recognized less dependence on radial glial cells and more complex multipolar morphologies, no mention was made of somal translocation. This is also true for the more recent studies in the rodent using immunofluorescence to reveal cell morphologies (Manent et al., 2005; Nakahira and Yuasa, 2005; Navarro-Quiroga et al., 2007). Nowakowski and Rakic do cite Morest (1970), studying the opossum brain, who identified an outer process extending through the hippocampal plate from the time the cell somata leave the VZ until they attain their final position. It is unclear if this data refers to somally translocating cells, or radial glial cell guided migration. From these studies, it is hence not yet possible to conclude if somal translocation is used in the hippocampus. Instead, another mode of migration, the "climbing mode" has recently been characterized. This occurs at late stages of cellular integration in the pyramidal cell layer, when migrating neurons are observed to exhibit multiple highly branched neuronal processes which interact with a number of radial fibers. Neurons are seen to switch radial fibers regularly, advancing in a zigzag manner through the hippocampal plate (Kitazawa et al., 2014). This mode of migration has never been characterized in the neocortex, may be specific to the hippocampus and may contribute to its less distinct lamination.

The pyramidal cell layer grows progressively from the subiculum to the dentate gyrus (DG), with the CA1 formed before the CA3 region. Studies in the rodent show that the migration time was shorter for CA1 pyramidal cells (4 days) than CA3 (5 days), although migration to both these regions is slower than cortical neurons migrating in the neocortex (Altman and Bayer, 1990b; Nakahira and Yuasa, 2005). Thus the CA1 layer becomes visible before the CA3, although its peak of neurogenesis (E18 in the rat) is a day later than the $\mathrm{CA} 3$ region (E17 in the rat). In the gradient of neurogenesis from the subiculum to the DG, CA1 neurogenesis is noticeably retarded and this has been associated with the requirement for thalamic inputs (Bayer, 1980). Alternatively, there is cumulative evidence for coordinated development and connectivity of different neuronal types within and outside the hippocampus (Bayer, 1980; Altman and Bayer, 1990b; Manent et al., 2005, 2006; Deguchi et al., 2011) which might help explain the comparatively longer "sojourning" time for CA3 pyramidal cells, which need to coordinate with DG granule cells. The curvature of the CA3 region and complexity of the migration path are also likely to contribute to this phenomenon. Indeed, unlike the CA1 region, CA3 cells not only have to migrate further, but they form a pyramidal cell layer which curves away from the neuroepithelium toward the DG. There is also a gradient of production of cells within the CA3 region itself, the regions closer to the CA1 region (CA3a and $\mathrm{b}$ subdivisions) forming before the region closest to the DG, and dorsal CA3 forming before ventral (Bayer, 1980). Indeed, CA3 cells destined for the hilar region (CA3c subdivision) have the furthest to travel, and they are eventually framed by the DG blades. Particular characteristics of radial glial cells at this stage of development are likely to be instrumental, 
playing a role as a substrate to guide CA3 cells to this destination. DG cells may use the same migratory path as they migrate tangentially from the dentate neuroepithelium to the DG region (Altman and Bayer, 1990a,b; Nakahira and Yuasa, 2005; Danglot et al., 2006; Barry et al., 2008; Khalaf-Nazzal and Francis, 2013). Barry et al. (2008) have shown that RG cells progressively express different markers, and the formation of the DG (and most probably the hilar CA3) region is particularly dependent on a radial glial subtype present at later stages of development, extending from the neuroepithelium to the DG region. This represents a difference compared to the CA1 region, which can still form in the presence of "earlier" RG cells. There is also a less distinct deep to superficial lamination in regions of the CA3c layer, with these cells, although grouped together, showing a certain amount of spreading compared to other CA regions (Bayer, 1980). All in all, and despite the shorter migration distances, the pattern of development and morphogenesis of the hippocampus seems relatively more complicated than the formation of the neocortex, related to its fields of different shapes and compositions, with the CA3 pyramidal cell layer being more complex than the CA1 in this respect. Cell heterogeneity within each of the CA1 and CA3 regions is also now a well-recognized phenomenon (Thompson et al., 2008; Dong et al., 2009; Christian et al., 2011; Slomianka et al., 2011; Graves et al., 2012; Nielsen et al., 2013). Time of birth, migration pathways, as well as extracellular factors all contribute to different cell identities in the adult.

Elizabeth Grove and colleagues characterized genetic markers distinguishing CA1 and CA3 fields, appearing during development (Tole et al., 1997). Many markers are now known in the adult, related to large-scale in situ hybridization data in the mouse (Thompson et al., 2008) which have revealed nine different subfields for the CA3 region, showing a remarkable relationship with different functional connectivity boundaries. Laser microdissection transcriptome studies are also adding to the identification of CA3-specific markers (Datson et al., 2004, 2009; Greene et al., 2009; Deguchi et al., 2011), which may in the future reveal novel developmental gene networks playing key roles specifically in CA3 migration and differentiation.

While the settling of pyramidal neurons in the CA regions occurs through local migration from the ammonic neuroepithelium, hippocampal interneurons have to migrate very long distances from their places of origin to their final destination in the hippocampus (reviewed by Danglot et al., 2006). Hippocampal interneurons destined for the CA region are produced in the ventral telencephalon of the mouse from E12 onwards (Soriano et al., 1986, 1989; Pleasure et al., 2000; Manent et al., 2006). When the transcription factor genes $D l x 1$ and 2 are inactivated, the migration of interneuron precursors is completely arrested in the subpallium, related to an upregulation of a cytoskeleton regulator, p21-activated serine/threonine kinase, PAK3 (Anderson et al., 1997; Cobos et al., 2007). Interneurons are indeed derived from the medial (MGE) and the caudal ganglionic eminences (CGE), which generate interneurons sequentially in two waves at E9-E12 and E12-E16, respectively (Anderson et al., 1997; Marin et al., 2001; Danglot et al., 2006). The first interneurons arrive in the hippocampus from E14 onwards. Interneurons use a tangential mode of migration to reach the pallium, migrating in streams, and progressively invading the hippocampus through the $\mathrm{MZ}$ and the IZ/subventricular zone (SVZ), with the MZ contributing the vast majority of interneurons (Manent et al., 2006). They terminate migration locally, with MGE interneurons reaching the strata pyramidale and oriens, and CGE interneurons arriving in the superficial strata lacunosum moleculare and radiatum (Tricoire et al., 2011). Although the routes of migration are clearly defined, the substrate of migration of interneuron precursors is not. It has been suggested that corticofugal axons might serve as a scaffold for interneuron migration by recruiting the adhesion molecule TAG-1 (Denaxa et al., 2001), but this remains controversial and needs to be further clarified (Denaxa et al., 2005). Similarly, while it has been proposed that radial glia could also constitute guides for interneuron migration final positioning (Polleux et al., 2002; Poluch and Juliano, 2007), these observations lack molecular evidence and still need to be explored. Because of the important diversity of interneurons in the CA fields (Fishell and Rudy, 2011), different approaches of genetic fate mapping have successfully correlated the precise location of neurogenesis in the subpallium with the generated subtype. Mice carrying a GFP transgene either under the control of the Gad65 or $N k \times 2-1$ promoters, allowed a specific tracking of the fate of interneuron precursors from the CGE or MGE respectively (Tricoire et al., 2011). There exists a striking association between the origin of interneurons, their respective markers and their electrophysiological properties. For instance, precursors originating from the MGE generate parvalbumin ${ }^{+}$, somatostatin ${ }^{+}$, and $\mathrm{nNOS}^{+}$interneurons with specific individual electrophysiological signatures, while the CGE-generated interneurons are cholecystokinin ${ }^{+}$, calretinin ${ }^{+}$, vasoactive intestinal peptide $(\mathrm{VIP})^{+}$and reelin ${ }^{+}$, each with distinct properties (Tricoire et al., 2011). These markers appear relatively homogenously distributed in the different strata constituting each of the CA fields, although subtle differences in number, morphology and layer distribution are recognized (Freund and Buzsaki, 1996; Matyas et al., 2004). For instance, while parvalbumin $^{+}$, calretinin ${ }^{+}$, and neuropeptide $\mathrm{Y}^{+}$interneurons are mainly located in the stratum pyramidale in the CA1 region, they are distributed throughout all strata of the CA3 region. Also, $\mathrm{VIP}^{+}$interneurons seem to be more abundant in CAl than in CA3 (Freund and Buzsaki, 1996; Matyas et al., 2004). The impact of these and other differences on CA1 vs. CA3 pyramidal cell functions remains to be completely explored.

All in all each of these steps of hippocampal development are instrumental to create the specific identities of the fields. Fundamental molecular, anatomical, and structural network differences between CA1 and CA3 regions suggest that these pyramidal cells have distinct functions. For instance, the recurrent network related to CA3 pyramidal cells differs greatly from the feed-forward network of the CA1 region. Functional intrinsic properties however, that might distinguish these pyramidal cell populations have not however been easily identified between CA1 and CA3 pyramidal cells (for example, Paz-Villagrán et al., 2004). It is possible that such differences at the single cell level could be very small. It has hence not been possible to ascertain the impact of potentially specific intrinsic properties compared to network effects on their functions. However, recently in vivo recordings from large sets of CA1 and CA3 pyramidal cells under various 
brain states and in different environments, clearly demonstrated significant differences in firing rates, spike burst propensity, spike entrainment by theta rhythm, and other spiking dynamics in a brain state-dependent manner (Mizuseki et al., 2012). Studies such as this are hence revealing functional measures to distinguish the two cell populations. Thus, CA1 and CA3 pyramidal cells seem to exhibit specific activity dynamics that may support their distinct computational roles.

\section{HUMAN HIPPOCAMPAL DEVELOPMENT AND DISORDERS}

As mentioned above, radial glial guided migration has been characterized in the fetal monkey hippocampus, suggesting that in primate, hippocampal development occurs in a similar fashion to rodent (Nowakowski and Rakic, 1979). The different steps of human hippocampal development have been characterized (Arnold and Trojanowski, 1996; Abraham et al., 2004) by immunohistochemistry experiments using fetal tissue. At 10 gestational weeks (GW), Abraham et al. described that the compact ammonic plate was not yet visible, but many proliferating cells were observed in the ammonic VZ. Cajal-Retzius cells were also observed in the $\mathrm{MZ}$ at this stage. Between 11 and $16 \mathrm{GW}$, the CA and DG fields became obvious and vimentin staining revealed radial glial like cells in the neuroepithelia, extending from the VZ to the pial surface (Abraham et al., 2004). In this same study, reelin positive interneurons were also identified in the $\mathrm{MZ}$ above the hippocampal plate from $14 \mathrm{GW}$ onwards. Proliferating cells become obvious in the dentate matrix from $14 \mathrm{GW}$ onwards and had receded by $21 \mathrm{GW}$, when a tertiary matrix had formed in the hilar region. These cells had distributed to the DG region by $16 \mathrm{GW}$. Quantitative Golgi studies have also revealed that dendritic arborization, spine development and synaptogenesis of pyramidal neurons (CA3) occur during the second and third trimesters, and may continue throughout childhood ( $\mathrm{Lu}$ et al., 2013). By 32-34 GW, it was described that neurons in CA2 and CA3 had undergone rapid enlargement and morphologic maturation, surpassing CA1, which still contained some immature neurons (Arnold and Trojanowski, 1996). Histological data has also been compared to 7-Tesla magnetic resonance imaging (MRI) data, which allowed a high resolution visualization of the different hippocampal fields in post-mortem fetal tissue (Milesi et al., 2014). These results are useful as a reference for the identification of human hippocampal abnormalities.

Hippocampal abnormalities have been found in association with a number of brain malformations, including agenesis of the corpus callosum, lissencephaly, holoprosencephaly, Fukuyama muscular dystrophy, polymicrogyria, heterotopia, focal cortical dysplasia, tuberous sclerosis, and schizencephaly (Sato et al., 2001; Porter et al., 2003; Montenegro et al., 2006; Kappeler et al., 2007; Fallet-Bianco et al., 2008; Donmez et al., 2009; Kuchukhidze et al., 2010). Such hippocampal defects in the past may have often been overshadowed by severe neocortical defects and not welldetailed due to the resolution of the MRI. It has more recently been shown in large cohorts that $30-55 \%$ of patients with cortical defects show hippocampal abnormalities (Donmez et al., 2009; Kuchukhidze et al., 2010). In these studies, bilateral and diffuse malformations were most often associated with such hippocampal abnormalities. Defects vary from small hippocampi and hypoplasia, enlarged hippocampi, to abnormally oriented hippocampi, related to abnormal gyration or infolding (Sato et al., 2001). Abnormal atrophy and severe neuronal loss can also be observed. Similar abnormalities are sometimes observed in febrile seizure, partial and refractory epilepsy patients, with no other obvious cortical abnormalities (Porter et al., 2003). Among cortical development disorders, those related to neuronal migration are the most highly associated with hippocampal abnormalities, as reported for lissencephaly (78\%) (Donmez et al., 2009). In two neuropathological studies of type 1 lissencephaly cases, the pyramidal cell layers were found to be diffuse, in some cases the CA and DG fields were difficult to distinguish, and a general hypoplasia was observed (Kappeler et al., 2007; Fallet-Bianco et al., 2008). As mentioned below, hippocampal defects are a signature of mice which are mutant for these type I lissencephaly genes (Khalaf-Nazzal and Francis, 2013). This suggests that some genes play conserved functions during hippocampal neuron migration in rodent and primate.

\section{MOUSE MUTANTS AND MOLECULAR MECHANISMS IMPORTANT FOR MIGRATION AND LAMINATION}

The pyramidal cell layer is crudely laminated along the radial axis, with deep to superficial, molecular, morphological and connectivity specificities (Altman and Bayer, 1990a,b,c; Thompson et al., 2008; Deguchi et al., 2011; Slomianka et al., 2011). Thus pyramidal cells are heterogeneous, their birth-date determines their final position, and both the timing of neurogenesis and external factors contribute to their identity. Concerning cell positioning, migratory mechanisms are finely tuned in different cell autonomous and non-cell-autonomous ways and play a key role for the appropriate development and lamination of the CA3 region. At the level of the individual cell, settled in the pyramidal cell layer, it is also sequentially connected by afferent fibers, which also follow a strict temporal and spatial order (Bayer, 1980; reviewed by Förster et al., 2006). Lamination, at both the somal and connectivity levels, may hence be critical for function.

\section{CELL AUTONOMOUS MECHANISMS}

The main cell intrinsic actors known to regulate the migratory activity of pyramidal cell precursors are major components of microtubule (MT) structures, or proteins linked to MTs, such as Microtubule Associated Proteins (MAPs) or MT motors. They regulate different aspects of saltatory cellular migration movements such as the elongation of the leading process or nuclear translocation. Some of these regulators, which are part of a generic program that commonly regulates neuronal migration in different cerebral regions such as the cortex, the cerebellum or the hippocampus, are also tightly regulated by region-specific cell to cell signaling.

Several mouse mutant lines for either tubulin or MT associated components present severe defects in the CA3 region. The ENU-induced mouse mutant showing a mutation in tubulin-alpha1a (Tuba1a) presents a severe fragmentation of the CA layers, including the CA3 region (Keays et al., 2007, see Figure 2 for schemas). The S140G mutation in Tubala might generate a haploinsufficiency phenotype with a defect in the incorporation of this mutant tubulin in MTs, which in turn is likely to perturb 

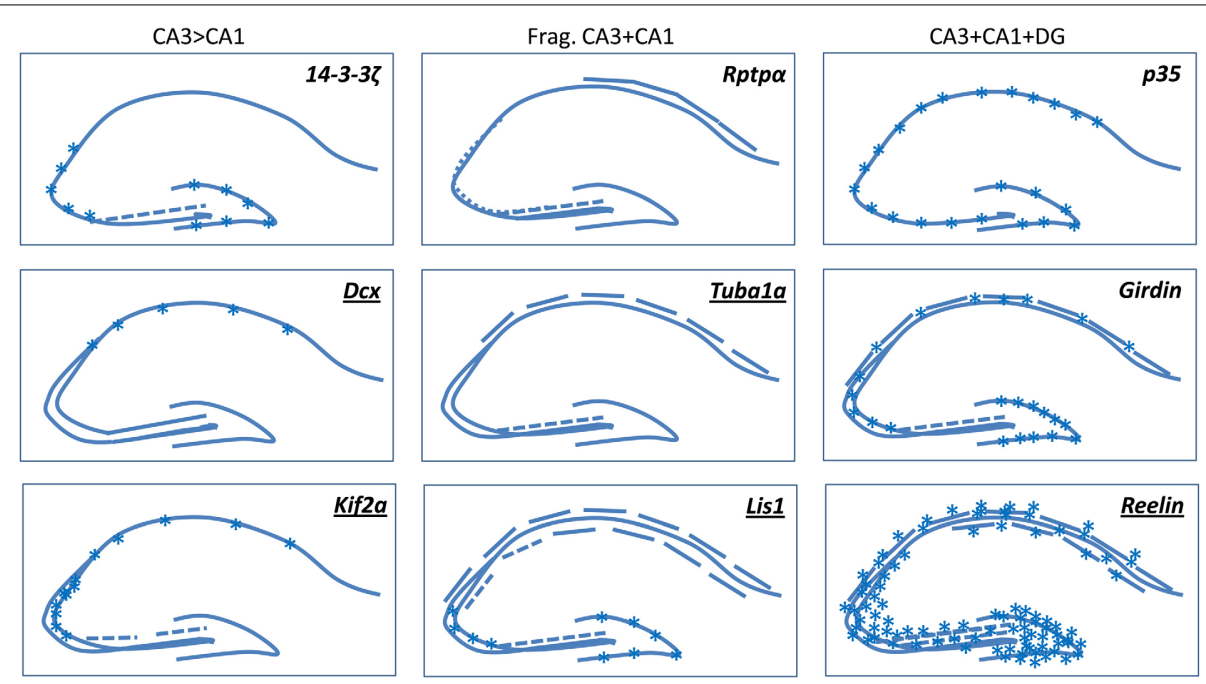

FIGURE 2 | A selection of mouse mutants showing somal lamination defects in the hippocampus. Underlined genes are known to be involved in cortical malformations in human. Frag, Fragmented. Broken lines indicate degrees of fragmentation. Asterisks indicate either heterotopic cells or diffusely packed cells. Schemas based on images presented in the following papers: (Del Río et al., 1997; Fleck et al., 2000; Wenzel et al., 2001; Corbo et al., 2002; Homma et al., 2003; Petrone et al., 2003; Kappeler et al., 2007; Keays et al., 2007; Enomoto et al., 2009; Cheah et al., 2012). Kif2a mutants die at birth, the PO images shown in Homma et al. (2003) are similar to Dcx-KO brains, we have hence extrapolated these data in our schema depicting adult brains.
MT growth rate and consequently migration. Following the identification of this mutant gene in the mouse, mutations were identified in TUBA1A in type 1 lissencephaly in human (Keays et al., 2007). Despite the importance of structural homology with several other existing tubulin isotypes in migrating neurons, these results reveal the unique properties of some individual tubulins.

When the expression of certain MAPs is perturbed in mice, similar phenotypes have been observed. Among them, the Doublecortin (Dcx) MAP (Francis et al., 1999; Gleeson et al., 1999), also involved in type 1 lissencephaly, when inactivated in mouse generates a striking anatomical defect, mainly restricted in the CA3 region, with an abnormal double layer of pyramidal neurons. Interestingly, partners of Dcx, spinophilin and Usp9x, when inactivated in the mouse give a similar phenotype (Friocourt et al., 2005; Bielas et al., 2007; Stegeman et al., 2013). The origin of the defects is likely an altered migration although the exact perturbed mechanisms have yet to be fully characterized (Corbo et al., 2002; Kappeler et al., 2007; NostenBertrand et al., 2008; Bazelot et al., 2012). Comparing with what is known for cortical pyramidal neurons and during interneuron migration, Dcx is likely to control neuronal migration by regulating branching and elongation of the leading process, and nuclear translocation, by stabilizing MT structures (Bai et al., 2003; Kappeler et al., 2006; Koizumi et al., 2006a; Belvindrah et al., 2011). The mouse model in particular has been extensively queried for CA3 functions (see "Electrophysiological, Behavioral, and Cognitive Phenotypes" section). Other members of the Dcx family also contribute to radial neuronal migration. Doublecortinlike kinase 1 (Dclk1) mutants show no obvious hippocampal abnormalities (Deuel et al., 2006; Koizumi et al., 2006b), however, double knockouts for Dcx and Dclk1, show both neocortical and hippocampal defects, conserving a severe fragmentation of the CA3 layer (Deuel et al., 2006). Mice deficient for both Dcx and Dclk2 show CA1 and CA3 lamination defects, without neocortical defects, and a reduced packing density of cells in the DG, as well as spontaneous seizures (Kerjan et al., 2009). Thus Dclk1 and 2 contribute to neuronal migration in other regions, although Dcx itself seems to have a primary importance in the CA3 region.

Another important MT regulator is the lissencephaly protein Lis1 that interacts within a multiple protein complex formed by dynactin/dynein and Ndel1. Lis 1 mouse mutants (Hirotsune et al., 1998) present severe defects in hippocampal development such as the presence of heterotopic pyramidal cells in both CA1 and CA3 regions, forming multiple distinct fragmented cell layers (Fleck et al., 2000), as well as granule cell dispersion and aberrant neurogenesis in the DG (Wang and Baraban, 2007, 2008; Hunt et al., 2012). Lis1 by interacting with Ndell and dynein participates in a dose-dependent manner to the coupling of the centrosome with the nucleus, an essential step that synchronizes the nuclear movement with the elongation of the leading process (Hirotsune et al., 1998; Shu et al., 2004). Lis1 also contributes to neuronal process stabilization per se during migration by interacting with MT motors (Sasaki et al., 2000; Smith et al., 2000). Lis1 and Dcx may act synergistically by regulating dynein function to mediate the coupling of the centrosome to the nucleus (Tanaka et al., 2004a) or by influencing MT stabilization and bundling (Sapir et al., 1997; Francis et al., 1999; Gleeson et al., 1999). Perhaps related to this partial functional overlap, Lis 1 and $D c x$ mutants present similarities in their respective pyramidal cell phenotypes but, interestingly, also noteworthy differences. While pyramidal cell somata are heterotopic and are less densely packed in both CA1 and CA3 in Lis 1 mutant mice (Fleck et al., 2000), Dcx mutants present mainly defects in the CA3 region, evoking once 
again possible divergent redundancies at least for the CA3 region, between these molecules.

The MT motor Kif2a is a further example of a protein with a MT function, which is required for hippocampal pyramidal cell organization in the mouse (Homma et al., 2003) and neocortical development in human (Poirier et al., 2013). This protein regulates MT dynamics by depolymerizing MTs. Mutant mice show a hippocampal phenotype, which is similar to Dcx mutants, the CA3 region is divided into two layers, and a thin heterotopic band is also seen during development in the CA1 region (Homma et al., 2003). The morphology of cells after settling in the CA1 pyramidal layer was analyzed in these mutants revealing an excess of axon collateral branching. This protein is likely to have pleiotropic functions, and an excess of branching may similarly perturb neuronal migration, as has been observed in Dcx mutant cells (Kappeler et al., 2006; Koizumi et al., 2006a; Belvindrah et al., 2011). A fragmented CA3 region is also seen in 14-3-35 mutant mice, once again resembling Dcx and Kif2a mutants (Cheah et al., 2012). It will be interesting to search for physical interactions between these intracellular proteins, likely to act in the same pathways in CA3 cells.

An important regulator of cytoskeletal proteins is Cyclin Dependent Kinase-5 (Cdk5). Cdk5 mediates phosphorylation of Neurofilament proteins, Map1b, Map2 as well as the MAP Tau. Genetic alteration of its expression (or its activator p35) revealed its important function in neuronal migration since the mutation generates a lack of a confined layer of pyramidal neurons in CA regions (Ohshima et al., 1996; Wenzel et al., 2001; Ohshima et al., 2007). Pyramidal neurons in both CA1 and CA3 are less densely packed and interrupted in places (Chae et al., 1997). Among other Cdk5 substrates are Nudel, a Lis1 interacting protein (Niethammer et al., 2000), Dcx (Tanaka et al., 2004b), Fak (Xie et al., 2003) and Disc-1, a protein associated with the centrosome and MTs (Ishizuka et al., 2011). Thus, Cdk5 fulfills a range of functions extending from nuclear translocation to remodeling of the cytoskeleton by regulating MT dynamics, and its function is critical for neocortical and hippocampal development.

Most of the cytoskeletal components shown to be important for neuronal migration are either intrinsic to MTs or are related to proteins associated with MTs. MT structures are thus required for the dynamics of the anterior part of the leading process, the elongation of the leading process per se and the remodeling of the perinuclear cage structure. How the different actin regulators also participate during neuronal migration, in synergy with the MT components, is not completely understood, even for the well studied migration of excitatory neurons in the neocortex. However, the function of the actin cytoskeleton has been revealed at the leading edge of the growth cone, where actin polymerization is finely tuned by Rho-GTPases, such as RhoA (likely regulated by p27Kip1, Kawauchi et al., 2006; Nguyen et al., 2006) and Racl (Kholmanskikh et al., 2003). The actin cytoskeleton is also important at different focal contacts initiated in part by $\mathrm{N}$-cadherins (Franco et al., 2011), where adhesions are formed, stabilized or removed. Moreover, the Rho effectors such as $\mathrm{mDia}$ and ROCK, interacting with the actin filaments located at the rear of the nucleus promote the actomyosin bundles required for nuclear translocation (Shinohara et al., 2012).
There is also molecular evidence of cross interactions between the MT and actin cytoskeletons, and of interest here, certain mouse mutants show hippocampal malformations. Among them, we can identify the Lis1/Cdc42/Iqgap1 complex where Lis1 could increase active Cdc42 and connect the plus-end MT to cortical actin required for neuronal motility (Kholmanskikh et al., 2006). Girdin is also an actin-binding protein which interacts with Disc1, itself interacting with the MT cytoskeleton (Enomoto et al., 2009). Girdin mouse mutants show hippocampal defects (see below). More recently, a conditional mouse mutant for the MTactin crosslinking factor 1a (Macf1), that is part of the plakin family and is supposed to bridge MTs with the actin meshwork, also revealed the importance of these regulatory cross-talks, since the mutants present single-band heterotopias in the CA1-CA3 regions (Goryunov et al., 2010). Thus correct functioning of the actin cytoskeleton seems clearly also critical for hippocampal cell migration.

One further similar mouse mutant, hippocampal lamination defect (Hld, Nowakowski and Davis, 1985), which arose spontaneously on the BALBc background, has also been described although to our knowledge the mutant gene (autosomal) is still unknown. In this mutant, the CA3c region was shown to be inverted, with later-generated neurons found in the deeper instead of superficial layers. This situation could also be true for certain of the above-mentioned mutants and the consequences of such an inversion on function are still unknown.

\section{NON-CELL-AUTONOMOUS MECHANISMS}

Cell autonomous processes are also entry points for specific modulation of neuronal migration by environmental cues provided by neighboring cells that could be Cajal-Retzius cells, radial glial cells, migrating interneurons or the migrating pyramidal cells themselves, as well as incoming mossy fibers for CA3 cells. Thus, despite the existence of an intrinsic program that defines subtype specificity according to the timing of neurogenesis (Deguchi et al., 2011), the overall architecture of a layered CA3 region is also determined by the cellular integration of complex environmental cues.

As mentioned previously, maintenance of radial glial scaffold integrity is crucial for appropriate glial-guided locomotion of pyramidal neurons. Different mouse mutant models present severe defects in neuronal migration in the CA regions when these glial fibers are disorganized. As in the neocortex, when these fibers lose their apical attachment or their parallel orientation, neuronal migration is strongly compromised. Components of the extracellular matrix are known to regulate neuronal migration during CA3 development. The $385 \mathrm{kDa}$ protein reelin, a major protein secreted by Cajal Retzius cells and shown to control cell positioning in the neocortex, is also implicated in the migratory mechanism of CA1 and CA3 pyramidal neurons. Reelin interacts with its receptors ApoER2/VLDLR to regulate intracellular effectors such as Dab1 (Hiesberger et al., 1999). Mutants for reelin (Stanfield and Cowan, 1979b; Niu et al., 2004) and ApoEr2/Vldlr (Trommsdorff et al., 1999) or their cytoplasmic effector Dab1 (Rice et al., 1998), present severe hippocampal development defects, among them, an absence of formation of a tight layer of pyramidal neurons, with cells only loosely organized. 
Since the radial glial scaffold is also severely perturbed in these reelin signaling hippocampal mutants (Forster et al., 2002; Weiss et al., 2003), the contribution of this signaling pathway to different aspects of neuronal migration is certainly multiple, and this is very likely to be a convergence point between noncell-autonomous and cell-autonomous regulators. For example, secreted reelin can control radial glial scaffold development, however it can also influence interaction of phosphorylated Dab1 with Lis1 within migrating neurons (Assadi et al., 2003; Zhang et al., 2007). The severe phenotype observed in Lis1 mutants could also be the consequence of a deregulation of the reelin signaling pathway within these neurons themselves. The other cell intrinsic regulator of neuronal migration, Cdk5, also converges with Reelin signaling (Ohshima et al., 2001; Beffert et al., 2004).

Another important regulator of cell migration in the CA3 region is the Receptor Protein Tyrosine Phosphatase, Rptp- $\alpha$ (gene name Ptpra). While Rptp- $\alpha$ mouse mutants present neuronal migration defects in CA regions, the primary cause of these defects is still unclear. Rptp- $\alpha$ has been shown to be important in the formation of apical dendrites (Ye et al., 2011). The Rptp$\alpha$ signaling pathway that activates Fyn and Src kinases might also contribute to the proper development of the radial glial scaffold for promoting appropriate neuronal migration, but in this case, this would be through a mechanism independent of reelin signaling (Petrone et al., 2003). More recently, mutants for Nuclear Factor Ib (Nfib) have also confirmed the importance of the integrity of the glial scaffold to provide the appropriate substrate for neuronal migration. Indeed, in these mutants the glial fibers originating in the ammonic neuroepithelium may fail to mature, compromising severely the development of the hippocampal structure, especially in the DG, and potentially also CA3 subregions (Barry et al., 2008).

The proper migration stimulatory cues for pyramidal neurons in the CA3 region are also provided by migratory interneurons through non-vesicular release of GABA and likely by the migratory pyramidal cells themselves, with glutamate release stimulating the migration through the activation of NMDA receptors (Manent et al., 2005). Thus multiple factors and multiple membrane proteins are likely to influence migration. The sensitivity of migrating neurons to extracellular cues can also be modulated by the turn-over of membrane receptors at the level of the neuronal growth cone. Intracellular factors such as MTs and MAPs are also likely to play a role in this process, adjusting the sensitivity to such extrinsic parameters by modulating the levels of proteins on the surface of the cell by endocytosis and recycling, as has been suggested for Dcx (Friocourt et al., 2001; Kizhatil et al., 2002; Yap et al., 2012).

\section{NON-GENETIC MECHANISMS PERTURBING CA MIGRATION}

Up till now we have mentioned genetic factors leading to perturbed CA cell migration. Other factors can lead to this phenotype including injection of methylazoxymethanol (MAM) a DNA alkylating agent (Cattabeni and Di Luca, 1997; Colacitti et al., 1999; Battaglia et al., 2003). This agent when injected in pregnant female rats or mice leads to brain malformations in the embryos, associated with perturbed hippocampal development and susceptibility to seizures (Chevassus-Au-Louis et al., 1998a,b;
Colacitti et al., 1999; Baraban et al., 2000). Focal heterotopias are related to a perturbation of radial glial cells during development (Paredes et al., 2006). Developmental mechanisms appear different though from mouse models mentioned above, CA1 heterotopic hippocampal neurons were characterized as being derived from the neocortex and integrated in both neocortical and hippocampal circuitry (Chevassus-Au-Louis et al., 1998b,a; Paredes et al., 2006). Hippocampal cells have been shown to have altered glutamate receptor subunit and transporter expression and the affected animals to suffer from epilepsy (Harrington et al., 2007). This model may be useful for further studying structural and functional defects related to CA migration disorders.

\section{TEMPORAL ASPECTS OF CA3 CELL MIGRATION AND THE INFLUENCE OF MOSSY FIBERS-AN ANALYSIS OF FURTHER MUTANTS}

The migration process follows a temporal sequence that is likely to impact cell connectivity (Stanfield and Cowan, 1979a; Bayer, 1980; Deguchi et al., 2011). While pyramidal neurons migrate uniformly and synchronously through the cortical wall along glial fibers, it has been proposed that the long pausing of CA3 cells in the IZ may be due to a necessary synchronization with the development of mossy fibers (largely starting at E17-E18). Initial observations showed that a major proportion of DG granule cells are born later than CA3 cells, and the DG blades are established in early postnatal stages (Altman and Bayer, 1990a; reviewed in Danglot et al., 2006). On the other hand, Deguchi et al. (2011) using sparse Thyl-mGFP reporter lines, were also able to show that some DG cells are born as early as E12 in the mouse hippocampus and that there is selective connectivity (neuronal specification and synaptogenesis) between CA3 and DG cells, and CA3 and CA1 cells, born at the same times. These latter data suggest that synchronization of the production of different cell types occurs and that microcircuits may be important in the hippocampus.

Although the production of connecting granule cells may therefore be temporally correlated with CA3 cell partners (Deguchi et al., 2011), it is possible that the CA3 pyramidal layer can assemble correctly even if DG formation is perturbed. However, as mentioned above, there do exist mouse mutants where both the DG and CA pyramidal layers are disorganized, for example, reelin (Del Río et al., 1997; Lambert de Rouvroit and Goffinet, 1998) and Lis1 mutants (Fleck et al., 2000; Wang and Baraban, 2007, 2008). The Girdin mutant also, related to the Disc1 pathway, and Grik2 "weaver" mutants show abnormal pathfinding of MFs and also some abnormal CA lamination or clusters of heterotopic cells (Sekiguchi et al., 1995; Enomoto et al., 2009). Differing from this, in the case of the Cxcr4 or Disc1 mouse mutants, granule cells are not guided properly to the DG region and remain accumulated in the migration path (Lu et al., 2002; Meyer and Morris, 2009; Kvajo et al., 2011), but in each case the pyramidal cell layer appears to form correctly, despite the granule cell abnormalities. It still remains possible on the other hand, that mossy fiber outgrowth occurs correctly in these mutants, despite abnormal granule cell position, hence still allowing for an effect of mossy fibers on CA3 cell migration. Conditional mutants are 
required to inactivate genes specifically in mossy fibers in order to verify pre-synaptic consequences on CA cell lamination.

A further set of mutants, with apparently correctly formed CA3 pyramidal and DG layers but more subtle perturbed mossy fiber targeting or pruning, are related to several axon guidance or adhesion molecules. For example inactivation of the semaphorin 3 receptors, plexin A3 and neuropilin 2 (Chen et al., 2000; Giger et al., 2000; Bagri et al., 2003), the guidance receptor ephrin B3 (Xu and Henkemeyer, 2009), and the adhesion molecule nectin (Honda et al., 2006), show mossy fibers which target infrapyramidal, as well as suprapyramidal regions, most probably due to abnormal fasciculation, targeting and pruning. Also, mouse mutants for serum response factor (Knöll et al., 2006), and adhesion molecules Chl1 (Montag-Sallaz et al., 2002), Ncam180 (Seki and Rutishauser, 1998) and cadherin (Bekirov et al., 2008; Williams et al., 2011), have mossy fibers which aberrantly synapse on CA3 somata within the pyramidal cell layer instead of apical dendrites in the suprapyramidal regions. Furthermore, in mutants for semaphorin 6 receptors plexin A2 and A4, the mossy fibers also continue to project either to the infra- and/or intrapyramidal regions (Suto et al., 2007; Tawarayama et al., 2010). In some of these cases of aberrant intrapyramidal connections, the CA3c region appears thickened, but this may be due to the presence of excess neuropil within the layer, more so than abnormal migration, although this remains to be formally demonstrated. A different problem was revealed by mutation of the grik2 gene, associated with autism spectrum disorder and intellectual disability, which slowed the structural and functional maturation of the hippocampal mossy fiber to CA3 pyramidal cell synapses (Lanore et al., 2012). These problems affecting mossy fiber fasciculation, targeting, synaptogenesis, and refinement do not hence answer the question if correct mossy fiber outgrowth and contact are strictly required for the final stages of CA3 cell migration and lamination, although this data seems to suggest that the migration of CA3 pyramidal neurons can occur relatively correctly, independently of mossy fibers. Specific bi-directional, trans-synaptic, interactions between DG and CA3 neurons remain however, critical to drive synapse formation.

\section{ELECTROPHYSIOLOGICAL, BEHAVIORAL, AND COGNITIVE PHENOTYPES}

In all mouse mutants for genes associated with type I lissencephaly, or other similar cortical malformations (Dcx, Kif $2 a$, Tuba1a, Lis1, reelin), a gradient of severity is observed at the functional and behavioral levels that parallels the gradient of severity that is observed at the cellular level. Consistent with an extensive neuronal disorganization in both the neocortex and hippocampus, reeler mice exhibit severe motor, behavioral, and emotional impairments (Falconer, 1951; Tueting et al., 1999, 2006; Gebhardt et al., 2002; Salinger et al., 2003). In the Lis1 model, the neuronal migration defects are associated with morphological and functional alterations of the Schaffer collateral-CA1 synapse and enhanced excitability in pyramidal neurons (Fleck et al., 2000; Jones and Baraban, 2007, 2009; Valdés-Sánchez et al., 2007; Greenwood et al., 2009). DG granule cells are also affected (Hunt et al., 2012). These mice exhibit spontaneous seizures (Hirotsune et al., 1998; Fleck et al., 2000; Jones and Baraban, 2009), as well as limited, albeit severe, cognitive deficits (Hirotsune et al., 1998; Lambert de Rouvroit and Goffinet, 1998; Paylor et al., 1999). Most studies which have been performed in Lis1 mutant mice have been focused on the CA1 region. Firstly, it was shown that CA1 heterotopic cells are more excitable compared to WT when hippocampal slices were subjected to increasingly elevated concentrations of potassium (Fleck et al., 2000). Single cell studies after stimulation of the Schaffer collaterals, further showed increased excitatory post-synaptic events (EPSPs) in mutant CA1 cells compared to WT. A laminar analysis of evoked EPSPs (with the recording electrode placed at different positions), showed that abnormally positioned heterotopic CA1 cells are also functionally innervated. Migration defects, EPSP abnormalities and some behavioral phenotypes were rescued by calpain inhibitors, which increase the quantities of Lis1 (Yamada et al., 2009; Sebe et al., 2013). Inhibitory post-synaptic currents (IPSCs) were recorded in CA1 cells and also found to be increased (ValdésSánchez et al., 2007). Furthermore, interneuron distribution and firing was abnormal in this model (Jones and Baraban, 2007, 2009). These combined data hence illustrate the multiple consequences on hippocampal circuits due to perturbed hippocampal development.

Unlike Lis1 mutants, Dcx-KO mice with cellular lamination defects largely restricted to the CA3 region, have provided a unique model to explore hippocampus-and CA3-dependent functions. At the clinical level, these mice exhibit spontaneous convulsive seizures and are more prone to seizures induced by chemoconvulsants than their WT littermates (Nosten-Bertrand et al., 2008). The precise anatomical characterization of the CA3 region revealed three distinct patterns of lamination in $D c x-\mathrm{KO}$ mice along the rostro-caudal axis, with CA3b and $\mathrm{c}$ subregions exhibiting both double and dispersed layers of pyramidal cell somata, while the CA3a region was mostly a single layer (Bazelot et al., 2012; Germain et al., 2013). The density and distribution of parvalbumin-containing interneurons were not affected in $\mathrm{Dcx}$-KO mice, and they were found to innervate pyramidal cell somata of both single and double (internal and external), layers. In addition, intracellular recordings, biocytin filling, as well as multi-electrode recordings showed that both layers of CA3 KO pyramidal cells exhibited an altered dendritic form and were more excitable than their WT counterparts (Bazelot et al., 2012). However, the bi-layer seems to have dramatic effects on pyramidal cell form, with the internal layer showing reduced basal dendrites, whereas the external layer showed reduced apical dendrites (Figure 3). Mossy fiber connections were also altered, related to the bi-layer, with some connections abnormally retained on the basal dendrites of the internal layer, whereas connections were interrupted on the apical dendrites of cells in the external layer, as they passed through the internal layer. The threshold current required to initiate an action potential was reduced in $D c x-\mathrm{KO}$ cells, and mean firing rates were increased. Thus, the absence of Dcx affects synaptic connectivity and results in enhanced pyramidal cell excitability.

At the behavioral level, $D c x$-KO mice were shown to be hyperactive in novel environments, less aggressive, and more ambidextrous than their WT littermates (Germain et al., 2013). Given its central position within the trisynaptic hippocampal pathway, the 


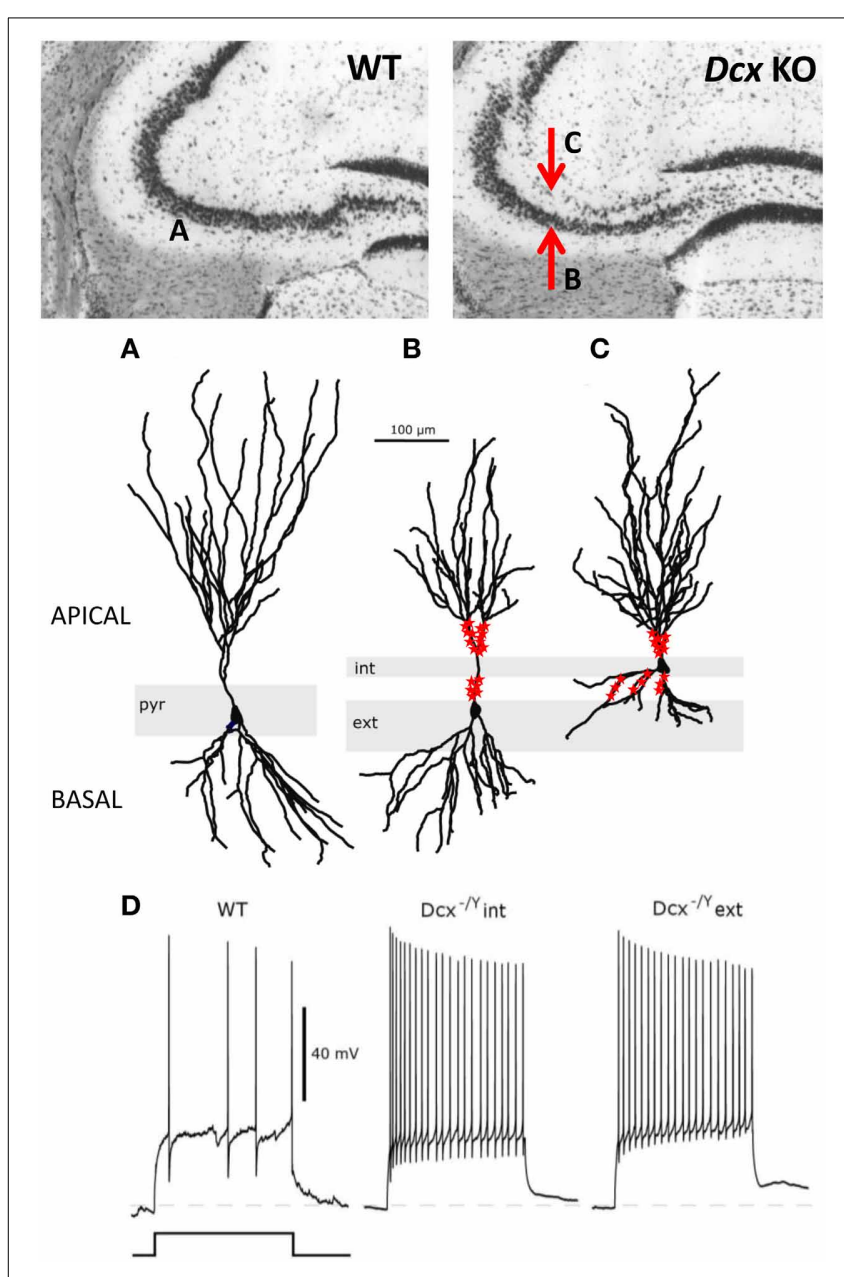

FIGURE 3 | Morphological and functional abnormalities in the Dcx-KO hippocampus. Upper images show coronal slices of the adult DcX-KO hippocampus (right) compared to wild-type (WT, left). Red arrows in the KO image point to the internal (upper) and external (lower) CA3 layers. Whole cell recordings and biocytin fills were performed to characterize internal (int) and external (ext) pyramidal cells. (A) WT cell; (B) KO external cell; (C) KO internal cell (taken and modified from Bazelot et al., 2012 Figure 5, published by John Wiley \& Sons Ltd). Analyses of cell morphologies revealed reduced lengths of apical dendrites for external layer cells and reduced lengths of basal dendrites for internal layer cells (Bazelot et al., 2012). Red labeling on dendrites schematizes mossy fiber innervation in the form of post-synaptic thorny excrescence-like spines. Note non-continuous innervation on apical dendrites of external layer cells, and basal as well as apical innervation on internal layer cells (schematizing data presented in Bazelot et al., 2012, Figure 4). (D) Whole cell recordings taken from Bazelot et al. (2012) Figure 6 (published by John Wiley \& Sons Ltd) revealed that KO cells are more excitable than their WT counterparts. In response to identical depolarizing current injection, $\mathrm{KO}$ cells fired at higher frequencies.

CA3 region may contribute to the prominent role of the hippocampus in episodic memory and spatial representation of the environment (Eichenbaum et al., 2012). However, interestingly, we have shown that $D c x$-KO mice exhibit normal spatial learning and contextual or cued memory as tested in the Barnes or water mazes, and in the fear-conditioning paradigms. $D c x-\mathrm{KO}$ mice also exhibited spared CA3-dependent cognitive functions such as rapid contextual representation, novelty detection, and one-trial short-term memory, tested with a large battery of tests such as fear conditioning, paired associate learning and object recognition (Germain et al., 2013). Strikingly, in another mouse model, the $D c x$ mutation was associated with lethality in hemizygous male mice, probably due to the different genetic backgrounds (Corbo et al., 2002). Interestingly however, both $D c x$ models are largely identical anatomically, with identical lamination defects largely restricted to the CA3 region. In addition, this study showed very mild behavioral deficits in Dcx heterozygous females, including reduced freezing in both cued and contextual fear conditioning tests, similarly identified in Germain et al. (2013), that could be indicative of an anxiety-related phenotype.

Thus, in Dcx mutants, the CA3 heterotopia is responsible for hyperexcitability and seizures, whereas hippocampal-dependent cognitive circuits may have at least partially adapted to the CA3 bi-layer. This differs from the situation in Lis 1 mice and other mutants, with a more severely malformed hippocampus, hyperexcitability and perturbed cognitive functions. Although, a genetic redundancy underlying functional compensatory mechanisms between Dcx and its closest homologs Dclk1 and Dclk2 has been specifically addressed and demonstrated to be important in the neocortex and CA1 region of murine Dcx models (Deuel et al., 2006; Koizumi et al., 2006b; Kerjan et al., 2009), the CA3 anatomical defects are present in single $D c x$ knockouts. These observations again suggest more complex and specific features of cell migration in the CA3 region. The presence of Dclk1 and 2 , and other potential compensatory proteins, in the developing CA3 region is not sufficient to allow correct neuronal migration and excitability, however the KO hippocampus still correctly performs hippocampus-dependent cognitive functions.

Two further mouse mutants showed mainly CA3 disorganization in the hippocampus, Kif 2a and 14-3-3 5 (Homma et al., 2003; Cheah et al., 2012) and it would hence be interesting to compare their behavioral phenotypes. Constitutive Kif 2a mutants, have multiple brain abnormalities and die within a day of birth (Homma et al., 2003), however, 14-3-35 mutants survive and exhibit striking behavioral deficits including hyperactivity, disrupted sensorimotor gating, and impaired learning and memory (Cheah et al., 2012). Some of these abnormalities are likely to be related to the hippocampal abnormalities. Notably though these mice also have developmental DG abnormalities, as well as severer abnormal mossy fiber targeting, differing hence from Dcx-KO mice.

\section{WHAT HAVE WE LEARNT FROM STUDYING THE CA3 REGION IN NEURONAL MIGRATION MUTANTS?}

1. The most striking observation from the murine models for genes involved in human neuronal migration disorders is that the CA3 region seems the most sensitive and consistently affected brain region. Indeed, all the mouse mutants for genes associated with type 1 lissencephaly, or other similar cortical malformations (Lis1, Dcx, Tuba1a, reelin, Kif2a), have a CA3 lamination defect as a common, and the most obvious, feature (Figure 2, Hirotsune et al., 1998; Lambert de Rouvroit and Goffinet, 1998; Fleck et al., 2000; Corbo et al., 2002; Homma et al., 2003; Kappeler et al., 2007; Keays et al., 
2007; Poirier et al., 2013). Human patients also have severe hippocampal abnormalities, however, these are not restricted to the CA3 region. The mouse CA3 phenotype is also often associated with other variable defects. CA3 lamination defects also seem to cluster in some mouse mutants of genes associated with neuropsychiatric disorders (Enomoto et al., 2009; Petrone et al., 2003). Thus CA3 lamination abnormalities in the mouse are correlated with neurodevelopmental cortical problems in human, and models derived from large-scale ENU mutagenesis projects may be tested to search for CA3 migration defects in order to easily select interesting models for further exploration (Keays et al., 2007; Furuse et al., 2012).

From a developmental point of view (section-Basic Steps of Hippocampal Development), it seems clear that CA3 cell migration is more complex than CA1. CA3 cells, especially in $\mathrm{CA} 3 \mathrm{~b}$ and $\mathrm{c}$ regions, have to migrate curved routes, which might involve several modes of migration, and particular features of radial glial cells that provide a cellular substrate. CA3 cell migration could hence require extra molecular and cellular pathways compared to CA1. The genes we mention in this review such as $D c x$, are strictly necessary to achieve CA3 cell migration correctly and even close homologs cannot compensate their function. In genetic terms, there seems hence to be lower redundancy in the CA3 region. Further study of CA3 mutants will help to reveal the very particular aspects of CA3 development, compared to CA1. Some of these mechanisms may also be required for human neocortical development.

It also remains possible that the CA3 region shows other susceptibilities. In the adult, CA3 cells are known to have a higher metabolic rate than CA1 cells, and to be more vulnerable to chronic stress and seizure-induced damages (Greene et al., 2009; Christian et al., 2011). Indeed, the CA3 is the most vulnerable subregion of the hippocampus in response to chronic stress and exhibits the most severe neuronal changes such as decrease in complexity and retraction of dendrites as compared to the CA1 subregion (Woolley et al., 1990; Watanabe et al., 1992). On the other hand, CA1 cells may be more susceptible to ischemia than CA3 pyramidal cells (Pulsinelli and Brierley, 1979; Zola-Morgan et al., 1986). CA3 cell organelle defects and increased cell death have also been identified in the $D c x$-KO postnatal hippocampus (Khalaf-Nazzal et al., 2013). It is too early to tell if this may be a consequence of the aberrant migration, related to cell stress, or alternatively a consequence of the intrinsic function of Dcx, associated with MTs, which may affect organelle trafficking and subsequently migration. We cannot rule out however, that early metabolic or other differences during development also contribute to CA3 vs. CA1 migration susceptibilities.

2. Slowed and arrested migration in CA3 mutants clearly leads to a situation resembling heterotopia, with a small distance along the radial axis between different layers of cell somata. In this respect, it is interesting to recall, that phylogenetic differences in lamination have arisen, such that a bi-laminar CA1 region exists naturally in various mammalian species (Slomianka et al., 2011). Bi-lamination of hippocampal pyramidal cells per se, therefore is not necessarily expected to lead to aberrant functional consequences. It does however seem detrimental in CA3 mouse mutants, at least at the level of morphology, mossy fiber connectivity and potentially hyperexcitability (Kerjan et al., 2009; Bazelot et al., 2012; Cheah et al., 2012). Mossy fiber connectivity abnormalities seem to go together with abnormal lamination, even if the inverse is not always true (see discussion in section Temporal Aspects of CA3 Cell Migration and the Influence of Mossy Fibers-An Analysis of Further Mutants).

3. Further connectivity and functional studies still need to be performed, especially taking into account different interneuron populations, because interneuron migration abnormalities have also been identified in some mutants ( $L i s 1, D c x$, Dcx/Dclk2, McManus et al., 2004; Kappeler et al., 2006; Kerjan et al., 2009). It is too early to tell if perturbed lamination contributes to abnormal positioning of hippocampal interneurons, even if the two processes may be coordinated (Manent et al., 2005; Lodato et al., 2011; Ciceri et al., 2013). During development, we and others have observed some interneuron and oligodendrocyte precursor cell disorganization within the developing CA3 layers (Kerjan et al., 2009; Khalaf-Nazzal et al., 2013). This may be related to a more diffuse organization of pyramidal cells (Khalaf-Nazzal et al., 2013).

In the Lis 1 model, as well as abnormal interneuron distribution, cell attached recordings showed that synaptic excitation of interneurons (EPSCs) was increased. IPSCs recorded in CA1 cells were also found to be increased (Jones and Baraban, 2007). The authors concluded that since precisely coordinated GABAergic activity is vital for the generation of oscillatory activity and place field precision in the hippocampus, these alterations in synaptic inhibition are likely to contribute to the seizures and the altered cognitive function observed. Loss of certain subpopulations is known to have a strong impact on susceptibility to epilepsy in other models (Cobos et al., 2005). Interneuron number and distribution can also change after seizures (Nosten-Bertrand et al., 2008; Kerjan et al., 2009). Interneuron function hence needs to be more closely examined in relation with CA3 phenotypes.

4. Concerning CA3-dependant cognitive function, it seems that it may be remarkably preserved in the $D c x$-KO despite a bi-lamination of the CA3 pyramidal layer. However in this model, the synaptic excitatory and inhibitory input seem to be preserved in both CA3 layers (Bazelot et al., 2012), suggesting that despite the enhanced pyramidal cell excitability, synaptic transmission and plasticity could still be retained to an extent compatible with normal CA3-dependent function. Some previous studies have clearly shown intact spatial navigation despite focal CA3 impairment (Nakazawa et al., 2003; Nakashiba et al., 2008). In addition, several alternative systems may also adapt and compensate to maintain hippocampal function. Of interest, impaired CA3- and hippocampal cognitive function are reported when migration defects expand to other hippocampal subregions, such as the DG (14-3-3ל mutants) or CA1 (Lis1 mutants).

5. CA3 deficits may be correlated with hyperexcitability and epilepsy, e.g., Dcx and Lis1 mutants, although defects in other cell types (e.g., interneurons), and in different hippocampal (e.g., CA1) and/or other brain regions (e.g., the neocortex) are 
very likely to also contribute to such a phenotype. Identifying the origins of hyperexcitability remains a complex subject, as does distinguishing between causative and neuroprotective mechanisms. Cataloguing the different mutants available for study and focusing on the most restricted phenotypes may help dissect out these pathogenic and pathophysiological mechanisms.

\section{FINAL CONCLUSIONS}

These fundamental studies concerning rodent models thus contribute to deepen our understanding of basic genetic and cellular mechanisms underlying lissencephaly and related disorders. They also shed light on specific CA3 molecular and cellular features, including more complex curved routes and longer pausing steps during cell migration, as well as a reduced potential of genetic and functional redundancy, that may all contribute to a higher vulnerability of this region. This may indeed extend to other human neurological and psychiatric disorders, for example different types of epilepsy and schizophrenia. In the past decade, thanks to rodent studies, the identification of cellular mechanisms underlying CA3 hyperactivity, including increased glutamatergic input from the amygdala, leading to CA3 interneuron loss, has significantly contributed to our understanding of psychotic-related symptoms such as social phobia and hallucinations (Liddle et al., 2000; Olypher et al., 2006; Lodge and Grace, 2007; Behrendt, 2010). Characterizing further these vulnerabilities will contribute to an improved pharmacological treatment of these morbid disorders in the future.

\section{AUTHOR CONTRIBUTIONS}

Richard Belvindrah, Marika Nosten-Bertrand, and Fiona Francis wrote the review.

\section{ACKNOWLEDGMENTS}

We thank Michael Bazelot, Richard Miles and other members of his lab for their contribution to Dcx KO data and discussions. We thank Jean-Christophe Poncer for his opinion on certain aspects of this review. We are grateful for financial support from the Agence National de la Recherche (ANR- 08-MNP-013), as well as from INSERM, including the Avenir program, the CNRS and UPMC, the Fondation Bettencourt Schueller, the Région Ile-deFrance, and the Fondation Jérôme Lejeune. Authors are associated with the BioPsy Labex project and the Ecole des Neurosciences de Paris Ile-de-France network.

\section{REFERENCES}

Abraham, H., Pérez-García, C. G., and Meyer, G. (2004). p73 and reelin in CajalRetzius cells of the developing human hippocampal formation. Cereb. Cortex 14, 484-495. doi: 10.1093/cercor/bhh010

Altman, J., and Bayer, S. A. (1990a). Mosaic organization of the hippocampal neuroepithelium and the multiple germinal sources of dentate granule cells. J. Comp. Neurol. 301, 325-342. doi: 10.1002/cne.903010302

Altman, J., and Bayer, S. A. (1990b). Prolonged sojourn of developing pyramidal cells in the intermediate zone of the hippocampus and their settling in the stratum pyramidale. J. Comp. Neurol. 301, 343-364. doi: 10.1002/cne.903010303

Altman, J., and Bayer, S. A. (1990c). Migration and distribution of two populations of hippocampal granule cell precursors during the perinatal and postnatal periods. J. Comp. Neurol. 301, 365-381. doi: 10.1002/cne.903010304
Anderson, S. A., Eisenstat, D. D., Shi, L., and Rubenstein, J. L. (1997). Interneuron migration from basal forebrain to neocortex: dependence on Dlx genes. Science 278, 474-476. doi: 10.1126/science.278.5337.474

Arnold, S. E., and Trojanowski, J. Q. (1996). Human fetal hippocampal development: I. Cytoarchitecture, myeloarchitecture, and neuronal morphologic features. J. Comp. Neurol. 367, 274-292. doi: 10.1002/(SICI)10969861(19960401)367:2<274::AID-CNE9>3.0.CO;2-2

Assadi, A. H., Zhang, G., Beffert, U., McNeil, R. S., Renfro, A. L., Niu, S., et al. (2003). Interaction of reelin signaling and Lis1 in brain development. Nat. Genet. 35, 270-276. doi: 10.1038/ng1257

Bagri, A., Cheng, H. J., Yaron, A., Pleasure, S. J., and Tessier-Lavigne, M. (2003). Stereotyped pruning of long hippocampal axon branches triggered by retraction inducers of the semaphorin family. Cell 113, 285-299. doi: 10.1016/S00928674(03)00267-8

Bai, J., Ramos, R. L., Ackman, J. B., Thomas, A. M., Lee, R. V., and LoTurco, J. J. (2003). RNAi reveals doublecortin is required for radial migration in rat neocortex. Nat. Neurosci. 6, 1277-1283. doi: 10.1038/nn1153

Baraban, S. C., Wenzel, H. J., Hochman, D. W., and Schwartzkroin, P. A. (2000). Characterization of heterotopic cell clusters in the hippocampus of rats exposed to methylazoxymethanol in utero. Epilepsy Res. 39, 87-102. doi: 10.1016/S09201211(99)00104-7

Barry, G., Piper, M., Lindwall, C., Moldrich, R., Mason, S., Little, E., et al. (2008). Specific glial populations regulate hippocampal morphogenesis. J. Neurosci. 28, 2328-12340. doi: 10.1523/JNEUROSCI.4000-08.2008

Battaglia, G., Bassanini, S., Granata, T., Setola, V., Giavazzi, A., and Pagliardini, S. (2003). The genesis of epileptogenic cerebral heterotopia: clues from experimental models. Epileptic Disord. 5, S51-S58.

Bayer, S. A. (1980). Development of the hippocampal region in the rat 1 . Neurogenesis examined with $3 \mathrm{H}$-thymidine autoradiography. J. Comp. Neurol. 190, 87-114. doi: 10.1002/cne.901900107

Bazelot, M., Simonnet, J., Dinocourt, C., Bruel-Jungerman, E., Miles, R., Fricker, D., et al. (2012). Cellular anatomy, physiology and epileptiform activity in the CA3 region of Dcx knockout mice: a neuronal lamination defect and its consequences. Eur. J. Neurosci. 35, 244-256. doi: 10.1111/j.1460-9568.2011.07962.x

Beffert, U., Weeber, E. J., Morfini, G., Ko, J., Brady, S. T., Tsai, L. H., et al. (2004). Reelin and cyclin-dependent kinase 5-dependent signals cooperate in regulating neuronal migration and synaptic transmission. J. Neurosci. 24, 1897-1906. doi: 10.1523/JNEUROSCI.4084-03.2004

Behrendt, R. P. (2010). Contribution of hippocampal region CA3 to consciousness and schizophrenic hallucinations. Neurosci. Biobehav. Rev. 34, 1121-1136. doi: 10.1016/j.neubiorev.2009.12.009

Bekirov, I. H., Nagy, V., Svoronos, A., Huntley, G. W., and Benson, D. L. (2008). Cadherin- 8 and N-cadherin differentially regulate pre- and postsynaptic development of the hippocampal mossy fiber pathway. Hippocampus 18, 349-363. doi: 10.1002/hipo.20395

Belvindrah, R., Nissant, A., and Lledo. P. M. (2011). Abnormal neuronal migration changes the fate of developing neurons in the postnatal olfactory bulb. J. Neurosci. 31, 7551-7562. doi: 10.1523/JNEUROSCI.6716-10.2011

Bielas, S. L., Serneo, F. F., Chechlacz, M., Deerinck, T. J., Perkins, G. A., Allen, P. B., et al. (2007). Spinophilin facilitates dephosphorylation of doublecortin by PP1 to mediate microtubule bundling at the axonal wrist. Cell 129, 579-591. doi: 10.1016/j.cell.2007.03.023

Bielle, F., Griveau, A., Narboux-Nême, N., Vigneau, S., Sigrist, M., Arber, S., et al. (2005). Multiple origins of Cajal-Retzius cells at the borders of the developing pallium. Nat. Neurosci. 8, 1002-1012. doi: 10.1038/nn1511

Cattabeni, F., and Di Luca, M. (1997). Developmental models of brain dysfunctions induced by targeted cellular ablations with methylazoxymethanol. Physiol. Rev. 77, 199-215.

Chae, T., Kwon, Y. T., Bronson, R., Dikkes, P., Li, E., and Tsai, L. H. (1997). Mice lacking p35, a neuronal specific activator of Cdk5, display cortical lamination defects, seizures, and adult lethality. Neuron 18, 29-42. doi: 10.1016/S08966273(01)80044-1

Cheah, P.-S., Ramshaw, H. S., Thomas, P. Q., Toyo-oka, K., Xu, X., Martin, S., et al. (2012). Neurodevelopmental and neuropsychiatric behaviour defects arise from 14-3-3ל deficiency. Mol. Psychiatry 17, 451-466. doi: 10.1038/mp.2011.158

Chen, H., Bagri, A., Zupicich, J. A., Zou, Y., Stoeckli, E., Pleasure, S. J., et al. (2000). Neuropilin-2 regulates the development of selective cranial and sensory nerves and hippocampal mossy fiber projections. Neuron 25, 43-56. doi: 10.1016/S0896-6273(00)80870-3 
Chevassus-Au-Louis, N., Congar, P., Represa, A., Ben-Ari, Y., and Gaïarsa, J. L. (1998b). Neuronal migration disorders: heterotopic neocortical neurons in CAl provide a bridge between the hippocampus and the neocortex. Proc. Natl. Acad. Sci. U.S.A. 95, 10263-10268. doi: 10.1073/pnas.95.17. 10263

Chevassus-Au-Louis, N., Rafiki, A., Jorquera, I., Ben-Ari, Y., and Represa, A. (1998a). Neocortex in the hippocampus: an anatomical and functional study of CA1 heterotopias after prenatal treatment with methylazoxymethanol in rats. J. Comp. Neurol. 394, 520-536. doi: 10.1002/(SICI)10969861(19980518)394:4<520::AID-CNE9>3.0.CO;2-3

Chizhikov, V. V., Lindgren, A. G., Mishima, Y., Roberts, R. W., Aldinger, K. A., Miesegaes, G. R., et al. (2010). Lmxla regulates fates and location of cells originating from the cerebellar rhombic lip and telencephalic cortical hem. Proc. Natl. Acad. Sci. U.S.A. 107, 10725-10730. doi: 10.1073/pnas. 0910786107

Christian, K. M., Miracle, A. D., Wellman, C. L., and Nakazawa, K. (2011). Chronic stress-induced hippocampal dendritic retraction requires CA3 NMDA receptors. Neuroscience 174, 26-36. doi: 10.1016/j.neuroscience.2010.11.033

Ciceri, G., Dehorter, N., Sols, I., Huang, Z. J., Maravall, M., and Marín, O. (2013). Lineage-specific laminar organization of cortical GABAergic interneurons. Nat. Neurosci. 16, 1199-1210. doi: 10.1038/nn.3485

Cobos, I., Borello, U., and Rubenstein, J. L. (2007). Dlx transcription factors promote migration through repression of axon and dendrite growth. Neuron 54, 873-888. doi: 10.1016/j.neuron.2007.05.024

Cobos, I., Calcagnotto, M. E., Vilaythong, A. J., Thwin, M. T., Noebels, J. L., Baraban, S. C., et al. (2005). Mice lacking Dlxl show subtype-specific loss of interneurons, reduced inhibition and epilepsy. Nat. Neurosci. 8, 1059-1068. doi: 10.1038/nn1499

Colacitti, C., Sancini, G., DeBiasi, S., Franceschetti, S., Caputi, A., Frassoni, C., et al. (1999). Prenatal methylazoxymethanol treatment in rats produces brain abnormalities with morphological similarities to human developmental brain dysgeneses. J. Neuropathol. Exp. Neurol. 58, 92-106. doi: 10.1097/00005072199901000-00010

Corbo, J. C., Deuel, T. A., Long, J. M., LaPorte, P., Tsai, E., Wynshaw-Boris, A., et al. (2002). Doublecortin is required in mice for lamination of the hippocampus but not the neocortex. J. Neurosci. 22, 7548-7557.

Danglot, L., Triller, A., and Marty, S. (2006). The development of hippocampal interneurons in rodents. Hippocampus 16, 1032-1060. doi: 10.1002/hipo. 20225

Datson, N. A., Meijer, L., Steenbergen, P. J., Morsink, M. C., van der Laan, S., Meijer, O. C., et al. (2004). Expression profiling in laser-microdissected hippocampal subregions in rat brain reveals large subregion-specific differences in expression. Eur. J. Neurosci. 20, 2541-2554. doi: 10.1111/j.1460-9568.2004.03738.x

Datson, N. A., Morsink, M. C., Steenbergen, P. J., Aubert, Y., Schlumbohm, C., Fuchs, E., et al. (2009). A molecular blueprint of gene expression in hippocampal subregions CA1, CA3, and DG is conserved in the brain of the common marmoset. Hippocampus 19, 739-752. doi: 10.1002/hipo.20555

Deguchi, Y., Donato, F., Galimberti, I., Cabuy, E., and Caroni, P. (2011). Temporally matched subpopulations of selectively interconnected principal neurons in the hippocampus. Nat. Neurosci. 14, 495-504. doi: 10.1038/nn.2768

Del Río, J. A., Heimrich, B., Borrell, V., Förster, E., Drakew, A., Alcántara, S., et al. (1997). A role for Cajal-Retzius cells and reelin in the development of hippocampal connections. Nature 385, 70-74. doi: 10.1038/385070a0

Denaxa, M., Chan, C. H., Schachner, M., Parnavelas, J. G., and Karagogeos, D. (2001). The adhesion molecule TAG-1 mediates the migration of cortical interneurons from the ganglionic eminence along the corticofugal fiber system. Development 128, 4635-4644.

Denaxa, M., Kyriakopoulou, K., Theodorakis, K., Trichas, G., Vidaki, M., Takeda, Y., et al. (2005). The adhesion molecule TAG-1 is required for proper migration of the superficial migratory stream in the medulla but not of cortical interneurons. Dev. Biol. 288, 87-99. doi: 10.1016/j.ydbio.2005.09.021

Deuel, T. A., Liu, J. S., Corbo, J. C., Yoo, S. Y., Rorke-Adams, L. B., and Walsh, C. A. (2006). Genetic interactions between doublecortin and doublecortinlike kinase in neuronal migration and axon outgrowth. Neuron 49, 41-53. doi: 10.1016/j.neuron.2005.10.038

Dong, H.-W., Swanson, L. W., Chen, L., Fanselow, M. S., and Toga, A. W. (2009). Genomic-anatomic evidence for distinct functional domains in hippocampal field CA1. Proc. Natl. Acad. Sci. U.S.A. 106, 11794-11799. doi: 10.1073/pnas.0812608106
Donmez, F. Y., Yildirim, M., Erkek, N., Demir Karacan, C., and Coskun, M. (2009). Hippocampal abnormalities associated with various congenital malformations. Childs Nerv. Syst. 25, 933-939. doi: 10.1007/s00381-009-0823-9

Eichenbaum, H., Sauvage, M., Fortin, N., Komorowski, R., and Lipton, P. (2012). Towards a functional organization of episodic memory in the medial temporal lobe. Neurosci. Biobehav. Rev. 36, 1597-1608. doi: 10.1016/j.neubiorev.2011.07.006

Enomoto, A., Asai, N., Namba, T., Wang, Y., Kato, T., Tanaka, M., et al. (2009). Roles of disrupted-in-schizophrenia 1-interacting protein girdin in postnatal development of the dentate gyrus. Neuron 63, 774-787. doi: 10.1016/j.neuron.2009.08.015

Falconer, D. S. (1951). Two new mutants, 'trembler' and 'reeler', with neurological actions in the house mouse (Mus musculus L.). J. Genet. 50, 192-200. doi: 10.1007/BF02996215

Fallet-Bianco, C., Loeuillet, L., Poirier, K., Loget, P., Chapon, F., Pasquier, L., et al. (2008). Neuropathological phenotype of a distinct form of lissencephaly associated with mutations in TUBA1A. Brain 131(Pt 9), 2304-2320. doi: 10.1093/brain/awn155

Fishell, G., and Rudy, B. (2011). Mechanisms of inhibition within the telencephalon: "where the wild things are." Annu. Rev. Neurosci. 34, 535-567. doi: 10.1146/annurev-neuro-061010-113717

Fleck, M. W., Hirotsune, S., Gambello, M. J., Phillips-Tansey, E., Suares, G., Mervis, R. F., et al. (2000). Hippocampal abnormalities and enhanced excitability in a murine model of human lissencephaly. J. Neurosci. 20, 2439-2450.

Forster, E., Tielsch, A., Saum, B., Weiss, K. H., Johanssen, C., Graus-Porta, D., et al. (2002). Reelin, disabled 1 , and beta 1 integrins are required for the formation of the radial glial scaffold in the hippocampus. Proc. Natl. Acad. Sci. U.S.A. 99, 13178-13183. doi: 10.1073/pnas.202035899

Förster, E., Zhao, S., and Frotscher, M. (2006). Laminating the hippocampus. Nat. Rev. Neurosci. 7, 259-267. doi: 10.1038/nrn1882

Francis, F., Koulakoff, A., Boucher, D., Chafey, P., Schaar, B., Vinet, M. C., et al. (1999). Doublecortin is a developmentally regulated, microtubuleassociated protein expressed in migrating and differentiating neurons. Neuron 23, 247-256. doi: 10.1016/S0896-6273(00)80777-1

Franco, S. J., Martinez-Garay, I., Gil-Sanz, C., Harkins-Perry, S. R., and Muller, U. (2011). Reelin regulates cadherin function via Dab1/Rapl to control neuronal migration and lamination in the neocortex. Neuron 69, 482-497. doi: 10.1016/j.neuron.2011.01.003

Freund, T. F., and Buzsaki, G. (1996). Interneurons of the hippocampus. Hippocampus 6, 347-470. doi: 10.1002/(SICI) 1098-1063(1996)6:4<347::AIDHIPO1>3.0.CO;2-I

Friocourt, G., Chafey, P., Billuart, P., Koulakoff, A., Vinet, M. C., Schaar, B. T., et al. (2001). Doublecortin interacts with mu subunits of clathrin adaptor complexes in the developing nervous system. Mol. Cell. Neurosci. 18, 307-319. doi: 10.1006/mcne.2001.1022

Friocourt, G., Kappeler, C., Saillour, Y., Fauchereau, F., Rodriguez, M. S., Bahi, N., et al. (2005). Doublecortin interacts with the ubiquitin protease DFFRX, which associates with microtubules in neuronal processes. Mol. Cell. Neurosci. 28, 153-164. doi: 10.1016/j.mcn.2004.09.005

Furuse, T., Yamada, I., Kushida, T., Masuya, H., Miura, I., Kaneda, H., et al. (2012). Behavioral and neuromorphological characterization of a novel Tubal mutant mouse. Behav. Brain Res. 227, 167-174. doi: 10.1016/j.bbr.2011.11.002

Gebhardt, C., Del Turco, D., Drakew, A., Tielsch, A., Herz, J., Frotscher, M., et al. (2002). Abnormal positioning of granule cells alters afferent fiber distribution in the mouse fascia dentata: morphologic evidence from reeler, apolipoprotein E receptor 2-, and very low density lipoprotein receptor knockout mice. J. Comp. Neurol. 445, 278-292. doi: 10.1002/cne. 10172

Germain, J., Bruel-Jungerman, E., Grannec, G., Denis, C., Lepousez, G., Giros, B., et al. (2013). Doublecortin knockout mice show normal hippocampaldependent memory despite CA3 lamination defects. PLOS ONE 8:e74992. doi: 10.1371/journal.pone.0074992

Giger, R. J., Cloutier, J. F., Sahay, A., Prinjha, R. K., Levengood, D. V., Moore, S. E., et al. (2000). Neuropilin-2 is required in vivo for selective axon guidance responses to secreted semaphorins. Neuron 25, 29-41. doi: 10.1016/S08966273(00)80869-7

Gleeson, J. G., Lin, P. T., Flanagan, L. A., and Walsh. C. A. (1999). Doublecortin is a microtubule-associated protein and is expressed widely by migrating neurons. Neuron 23, 257-271. doi: 10.1016/S0896-6273(00)80778-3 
Goryunov, D., He, C. Z., Lin, C. S., Leung, C. L., and Liem. R. K. (2010). Nervoustissue-specific elimination of microtubule-actin crosslinking factor 1a results in multiple developmental defects in the mouse brain. Mol. Cell. Neurosci. 44, 1-14 doi: 10.1016/j.mcn.2010.01.010

Götz, M., and Huttner, W. B. (2005). The cell biology of neurogenesis. Nat. Rev. Mol. Cell Biol. 6, 777-788. doi: 10.1038/nrm1739

Graves, A. R., Moore, S. J., Bloss, E. B., Mensh, B. D., Kath, W. L., and Spruston, N. (2012). Hippocampal pyramidal neurons comprise two distinct cell types that are countermodulated by metabotropic receptors. Neuron $76,776-789$. doi: 10.1016/j.neuron.2012.09.036

Greene, J. G., Borges, K., and Dingledine, R. (2009). Quantitative transcriptional neuroanatomy of the rat hippocampus: evidence for wide-ranging, pathwayspecific heterogeneity among three principal cell layers. Hippocampus 19, 253-264. doi: 10.1002/hipo.20502

Greenwood, J. S., Wang, Y., Estrada, R. C., Ackerman, L., Ohara, P. T., and Baraban, S. C. (2009). Seizures, enhanced excitation, and increased vesicle number in Lis1 mutant mice. Ann. Neurol. 66, 644-653. doi: 10.1002/ana.21775

Gupta, A., Tsai, L. H., and Wynshaw-Boris, A. (2002). Life is a journey: a genetic look at neocortical development. Nat. Rev. Genet. 3, 342-355. doi: $10.1038 /$ nrg799

Harrington, E. P., Möddel, G., Najm, I. M., and Baraban, S. C. (2007). Altered glutamate receptor - transporter expression and spontaneous seizures in rats exposed to methylazoxymethanol in utero. Epilepsia 48, 158-168. doi: 10.1111/j.15281167.2006.00838.x

Hiesberger, T., Trommsdorff, M., Howell, B. W., Goffinet, A., Mumby, M. C., Cooper, J. A., et al. (1999). Direct binding of reelin to VLDL receptor and ApoE receptor 2 induces tyrosine phosphorylation of disabled-1 and modulates tau phosphorylation. Neuron 24, 481-489. doi: 10.1016/S0896-6273(00) 80861-2

Hirotsune, S., Fleck, M. W., Gambello, M. J., Bix, G. J., Chen, A., Clark, G. D., et al. (1998). Graded reduction of Pafahlbl (Lis1) activity results in neuronal migration defects and early embryonic lethality. Nat. Genet. 19, 333-339. doi: $10.1038 / 1221$

Hoch, R. V., Rubenstein, J. L. R., and Pleasure, S. (2009). Genes and signaling events that establish regional patterning of the mammalian forebrain. Semin. Cell Dev. Biol. 20, 378-386. doi: 10.1016/j.semcdb.2009.02.005

Homma, N., Takei, Y., Tanaka, Y., Nakata, T., Terada, S., Kikkawa, M., et al. (2003). Kinesin superfamily protein 2A (KIF2A) functions in suppression of collateral branch extension. Cell 114, 229-239. doi: 10.1016/S0092-8674(03) 00522-1

Honda, T., Sakisaka, T., Yamada, T., Kumazawa, N., Hoshino, T., Kajita, M., et al. (2006). Involvement of nectins in the formation of puncta adherentia junctions and the mossy fiber trajectory in the mouse hippocampus. Mol. Cell. Neurosci. 31, 315-325. doi: 10.1016/j.mcn.2005.10.002

Hunt, R. F., Dinday, M. T., Hindle-Katel, W., and Baraban, S. C. (2012). LIS1 deficiency promotes dysfunctional synaptic integration of granule cells generated in the developing and adult dentate gyrus. J. Neurosci. 32, 12862-12875. doi: 10.1523/JNEUROSCI.1286-12.2012

Ishizuka, K., Kamiya, A., Oh, E. C., Kanki, H., Seshadri, S., Robinson, J. F., et al. (2011). DISC1-dependent switch from progenitor proliferation to migration in the developing cortex. Nature 473, 92-96. doi: 10.1038/nature09859

Jones, D. L., and Baraban, S. C. (2007). Characterization of inhibitory circuits in the malformed hippocampus of Lis1 mutant mice. J. Neurophysiol. 98, 2737-2746. doi: 10.1152/jn.00938.2007

Jones, D. L., and Baraban, S. C. (2009). Inhibitory inputs to hippocampal interneurons are reorganized in Lis1 mutant mice. J. Neurophysiol. 102, 648-658. doi: 10.1152/jn.00392.2009

Kappeler, C., Dhenain, M., Phan Dinh Tuy, F., Saillour, Y., Marty, S., Fallet-Bianco, C., et al. (2007). Magnetic resonance imaging and histological studies of corpus callosal and hippocampal abnormalities linked to doublecortin deficiency. J. Comp. Neurol. 500, 239-254. doi: 10.1002/cne.21170

Kappeler, C., Saillour, Y., Baudoin, J. P., Tuy, F. P., Alvarez, C., Houbron, C., et al. (2006). Branching and nucleokinesis defects in migrating interneurons derived from doublecortin knockout mice. Hum. Mol. Genet. 15, 1387-1400. doi: $10.1093 / \mathrm{hmg} / \mathrm{ddl} 062$

Kawauchi, T., Chihama, K., Nabeshima, Y., and Hoshino, M. (2006). Cdk5 phosphorylates and stabilizes p27kipl contributing to actin organization and cortical neuronal migration. Nat. Cell Biol. 8, 17-26. doi: 10.1038/ncb1338
Keays, D. A., Tian, G., Poirier, K., Huang, G. J., Siebold, C., Cleak, J., et al. (2007). Mutations in alpha-tubulin cause abnormal neuronal migration in mice and lissencephaly in humans. Cell 128, 45-57. doi: 10.1016/j.cell.2006. 12.017

Kerjan, G., Koizumi, H., Han, E. B., Dubé, C. M., Djakovic, S. N., Patrick, G. N., et al. (2009). Mice lacking doublecortin and doublecortin-like kinase 2 display altered hippocampal neuronal maturation and spontaneous seizures. Proc. Natl. Acad. Sci. U.S.A. 106, 6766-6771. doi: 10.1073/pnas.0812687106

Khalaf-Nazzal, R., Bruel-Jungerman, E., Rio, J.-P., Bureau, J., Irinopoulou, T., Sumia, I., et al. (2013). Organelle and cellular abnormalities associated with hippocampal heterotopia in neonatal doublecortin knockout mice. PLoS ONE 8:e72622. doi: 10.1371/journal.pone.0072622

Khalaf-Nazzal, R., and Francis, F. (2013). Hippocampal development - Old and new findings. Neuroscience 248C, 225-242. doi: 10.1016/j.neuroscience.2013. 05.061

Kholmanskikh, S. S., Dobrin, J. S., Wynshaw-Boris, A., Letourneau, P. C., and Ross, M. E. (2003). Disregulated RhoGTPases and actin cytoskeleton contribute to the migration defect in Lis1-deficient neurons. J. Neurosci. 23, 8673-8681.

Kholmanskikh, S. S., Koeller, H. B., Wynshaw-Boris, A., Gomez, T., Letourneau, P. C., and Ross, M. E. (2006). Calcium-dependent interaction of Lis 1 with IQGAP1 and Cdc42 promotes neuronal motility. Nat. Neurosci. 9, 50-57. doi: $10.1038 / \mathrm{nn} 1619$

Kitazawa, A., Kubo, K., Hayashi, K., Matsunaga, Y., Ishii, K., and Nakajima, K. (2014). Hippocampal pyramidal neurons switch from a multipolar migration mode to a novel "Climbing" migration mode during development. J. Neurosci. 34, 1115-1126. doi: 10.1523/JNEUROSCI.2254-13.2014

Kizhatil, K., Wu, Y. X., Sen, A., and Bennett, V. (2002). A new activity of doublecortin in recognition of the phospho-FIGQY tyrosine in the cytoplasmic domain of neurofascin. J. Neurosci. 22, 7948-7958.

Knöll, B., Kretz, O., Fiedler, C., Alberti, S., Schütz, G., Frotscher, M., et al. (2006). Serum response factor controls neuronal circuit assembly in the hippocampus. Nat. Neurosci. 9, 195-204. doi: 10.1038/nn1627

Koizumi, H., Higginbotham, H., Poon, T., Tanaka, T., Brinkman, B. C., and Gleeson, J. G. (2006a). Doublecortin maintains bipolar shape and nuclear translocation during migration in the adult forebrain. Nat. Neurosci. 9, 779-786. doi: $10.1038 / \mathrm{nn} 1704$

Koizumi, H., Tanaka, T., and Gleeson, J. G. (2006b). Doublecortin-like kinase functions with doublecortin to mediate fiber tract decussation and neuronal migration. Neuron 49, 55-66. doi: 10.1016/j.neuron.2005.10.040

Kriegstein, A., Noctor, S., and Martínez-Cerdeño, V. (2006). Patterns of neural stem and progenitor cell division may underlie evolutionary cortical expansion. Nat. Rev. Neurosci. 7, 883-890. doi: 10.1038/nrn2008

Kuchukhidze, G., Koppelstaetter, F., Unterberger, I., Dobesberger, J., Walser, G., Zamarian, L., et al. (2010). Hippocampal abnormalities in malformations of cortical development: MRI study. Neurology 74, 1575-1582. doi: 10.1212/WNL.0b013e3181df09b6

Kvajo, M., McKellar, H., Drew, L. J., Lepagnol-Bestel, A. M., Xiao, L., Levy, R. J., et al. (2011). Altered axonal targeting and short-term plasticity in the hippocampus of Disc1 mutant mice. Proc. Natl. Acad. Sci. U.S.A. 108, E1349-E1358. doi: 10.1073/pnas.1114113108

Lambert de Rouvroit, C., and Goffinet, A. M. (1998). The reeler mouse as a model of brain development. Adv. Anat. Embryol. Cell Biol. 150, 1-106. doi: 10.1007/978-3-642-72257-8_1

Lanore, F., Labrousse, V. F., Szabo, Z., Normand, E., Blanchet, C., and Mulle, C. (2012). Deficits in morphofunctional maturation of hippocampal mossy fiber synapses in a mouse model of intellectual disability. J. Neurosci. 32, 17882-17893. doi: 10.1523/JNEUROSCI.2049-12.2012

Liddle, P. F., Lane, C. J., and Ngan, E. T. (2000). Immediate effects of risperidone on cortico-striato-thalamic loops and the hippocampus. Br. J. Psychiatry 177, 402-407. doi: 10.1192/bjp.177.5.402

Lodato, S., Rouaux, C., Quast, K. B., Jantrachotechatchawan, C., Studer, M., Hensch, T. K., et al. (2011). Excitatory projection neuron subtypes control the distribution of local inhibitory interneurons in the cerebral cortex. Neuron 69, 763-779. doi: 10.1016/j.neuron.2011.01.015

Lodge, D. J., and Grace, A. A. (2007). Aberrant hippocampal activity underlies the dopamine dysregulation in an animal model of schizophrenia. J. Neurosci. 27, 11424-11430. doi: 10.1523/JNEUROSCI.2847-07.2007 
Lu, D., He, L., Xiang, W., Ai, W. M., Cao, Y., Wang, X. S., et al. (2013). Somal and dendritic development of human CA3 pyramidal neurons from midgestation to middle childhood: a quantitative Golgi study. Anat. Rec. (Hoboken). 296, 123-132. doi: 10.1002/ar.22616

Lu, M., Grove, E. A., and Miller, R. J. (2002). Abnormal development of the hippocampal dentate gyrus in mice lacking the CXCR4 chemokine receptor. Proc. Natl. Acad. Sci. U.S.A. 99, 7090-7095. doi: 10.1073/pnas.092013799

Manent, J. B., Demarque, M., Jorquera, I., Pellegrino, C., Ben-Ari, Y., Aniksztejn, L., et al. (2005). A noncanonical release of GABA and glutamate modulates neuronal migration. J. Neurosci. 25, 4755-4765. doi: 10.1523/JNEUROSCI.055305.2005

Manent, J.-B., Jorquera, I., Ben-Ari, Y., Aniksztejn, L., and Represa, A. (2006). Glutamate acting on AMPA but not NMDA receptors modulates the migration of hippocampal interneurons. J. Neurosci. 26, 5901-5909. doi: 10.1523/JNEUROSCI.1033-06.2006

Marin, O., Yaron, A., Bagri, A., Tessier-Lavigne, M., and Rubenstein, J. L. (2001). Sorting of striatal and cortical interneurons regulated by semaphorinneuropilin interactions. Science 293, 872-875. doi: 10.1126/science.1061891

Matyas, F., Freund, T. F., and Gulyas, A. I. (2004). Immunocytochemically defined interneuron populations in the hippocampus of mouse strains used in transgenic technology. Hippocampus 14, 460-481. doi: 10.1002/hipo.10191

McManus, M. F., Nasrallah, I. M., Pancoast, M. M., Wynshaw-Boris, A., and Golden, J. A. (2004). Lis1 is necessary for normal non-radial migration of inhibitory interneurons. Am. J. Pathol. 165, 775-784. doi: 10.1016/S00029440(10)63340-8

Meyer, K. D., and Morris, J. A. (2009). Discl regulates granule cell migration in the developing hippocampus. Hum. Mol. Genet. 18, 3286-3297. doi: $10.1093 / \mathrm{hmg} / \mathrm{ddp} 266$

Milesi, G., Garbelli, R., Zucca, I., Aronica, E., Spreafico, R., and Frassoni, C. (2014). Assessment of human hippocampal developmental neuroanatomy by means of ex-vivo 7T magnetic resonance imaging. Int. J. Dev. Neurosci. 34, 33-41. doi: 10.1016/j.ijdevneu.2014.01.002

Mizuseki, K., Royer, S., Diba, K., and Buzsáki, G. (2012). Activity dynamics and behavioral correlates of CA3 and CA1 hippocampal pyramidal neurons. Hippocampus 22, 1659-1680. doi: 10.1002/hipo.22002

Montag-Sallaz, M., Schachner, M., and Montag, D. (2002). Misguided axonal projections, neural cell adhesion molecule 180 mRNA upregulation, and altered behavior in mice deficient for the close homolog of L1. Mol. Cell. Biol. 22, 7967-7981. doi: 10.1128/MCB.22.22.7967-7981.2002

Montenegro, M. A., Kinay, D., Cendes, F., Bernasconi, A., Bernasconi, N., Coan, A. C., et al. (2006). Patterns of hippocampal abnormalities in malformations of cortical development. J. Neurol. Neurosurg. Psychiatry 77, 367-371. doi: 10.1136/jnnp.2005.070417

Morest, D. K. (1970). A study of neurogenesis in the forebrain of opossum pouch young. Z. Anat. Entwicklungsgesch. 130, 265-305. doi: 10.1007/BF00520999

Nadarajah, B., and Parnavelas, J. G. (2002). Modes of neuronal migration in the developing cerebral cortex. Nat. Rev. Neurosci. 3, 423-432. doi: 10.1038/ nrn845

Nakahira, E., and Yuasa, S. (2005). Neuronal generation, migration, and differentiation in the mouse hippocampal primoridium as revealed by enhanced green fluorescent protein gene transfer by means of in utero electroporation. J. Comp. Neurol. 483, 329-340. doi: 10.1002/cne.20441

Nakashiba, T., Young, J. Z., McHugh, T. J., Buhl, D. L., and Tonegawa, S. (2008). Transgenic inhibition of synaptic transmission reveals role of CA3 output in hippocampal learning. Science 319, 1260-1264. doi: 10.1126/science. 1151120

Nakazawa, K., Sun, L. D., Quirk, M. C., Rondi-Reig, L., Wilson, M. A., and Tonegawa, S. (2003). Hippocampal CA3 NMDA receptors are crucial for memory acquisition of one-time experience. Neuron 38, 305-315. doi: 10.1016/S0896-6273(03)00165-X

Navarro-Quiroga, I., Chittajallu, R., Gallo, V., and Haydar, T. F. (2007). Longterm, selective gene expression in developing and adult hippocampal pyramidal neurons using focal in utero electroporation. J. Neurosci. 27, 5007-5011. doi: 10.1523/JNEUROSCI.0867-07.2007

Nguyen, L., Besson, A., Heng, J. I., Schuurmans, C., Teboul, L., Parras, C., et al. (2006). p27kipl independently promotes neuronal differentiation and migration in the cerebral cortex. Genes Dev. 20, 1511-1524. doi: 10.1101/gad.377106

Nielsen, J. V., Thomassen, M., Møllgård, K., Noraberg, J., and Jensen, N. A. (2013). Zbtb20 defines a hippocampal neuronal identity through direct repression of genes that control projection neuron development in the isocortex. Cereb. Cortex. doi: 10.1093/cercor/bhs400. [Epub ahead of print].

Niethammer, M., Smith, D. S., Ayala, R., Peng, J., Ko, J., Lee, M. S., et al. (2000). NUDEL is a novel Cdk5 substrate that associates with LIS1 and cytoplasmic dynein. Neuron 28, 697-711. doi: 10.1016/S0896-6273(00)00147-1

Niu, S., Renfro, A., Quattrocchi, C. C., Sheldon, M., and D'Arcangelo, G. (2004). Reelin promotes hippocampal dendrite development through the VLDLR/ApoER2-Dab1 pathway. Neuron 41, 71-84. doi: 10.1016/S08966273(03)00819-5

Nosten-Bertrand, M., Kappeler, C., Dinocourt, C., Denis, C., Germain, J., Phan Dinh Tuy, F., et al. (2008). Epilepsy in Dcx knockout mice associated with discrete lamination defects and enhanced excitability in the hippocampus. PLoS ONE 3:e2473. doi: 10.1371/journal.pone.0002473

Nowakowski, R. S., and Davis, T. L. (1985). Dendritic arbors and dendritic excrescences of abnormally positioned neurons in area CA3c of mice carrying the mutation "hippocampal lamination defect." J. Comp. Neurol. 239, 267-275. doi: $10.1002 / \mathrm{cne} .902390303$

Nowakowski, R. S., and Rakic, P. (1979). The mode of migration of neurons to the hippocampus: a golgi and electron microscopic analysis in foetal rhesus monkey. J. Neurocytol. 8, 697-718. doi: 10.1007/BF01206671

Ohshima, T., Hirasawa, M., Tabata, H., Mutoh, T., Adachi, T., Suzuki, H., et al. (2007). Cdk5 is required for multipolar-to-bipolar transition during radial neuronal migration and proper dendrite development of pyramidal neurons in the cerebral cortex. Development 134, 2273-2282. doi: 10.1242/dev. 02854

Ohshima, T., Ogawa, M., Veeranna, Hirasawa, M., Longenecker, G., Ishiguro, K., et al. (2001). Synergistic contributions of cyclin-dependant kinase 5/p35 and Reelin/Dabl to the positioning of cortical neurons in the developing mouse brain. Proc. Natl. Acad. Sci. U.S.A. 98, 2764-2769. doi: 10.1073/pnas. 051628498

Ohshima, T., Ward, J. M., Huh, C. G., Longenecker, G., Veeranna, Pant, H. C., et al. (1996). Targeted disruption of the cyclin-dependent kinase 5 gene results in abnormal corticogenesis, neuronal pathology and perinatal death. Proc. Natl. Acad. Sci. U.S.A. 93, 11173-11178. doi: 10.1073/pnas.93.20.11173

Olypher, A. V., Klement, D., and Fenton, A. A. (2006). Cognitive disorganization in hippocampus: a physiological model of the disorganization in psychosis. J. Neurosci. 26, 158-168. doi: 10.1523/JNEUROSCI.2064-05.2006

Paredes, M., Pleasure, S. J., and Baraban, S. C. (2006). Embryonic and early postnatal abnormalities contributing to the development of hippocampal malformations in a rodent model of dysplasia. J. Comp. Neurol. 495, 133-148. doi: $10.1002 /$ cne. 20871

Paylor, R., Hirotsune, S., Gambello, M. J., Yuva-Paylor, L., Crawley, J. N., and Wynshaw-Boris, A. (1999). Impaired learning and motor behavior in heterozygous Pafahlb1 (Lis1) mutant mice. Learn. Mem. 6, 521-537. doi: 10.1101/lm.6.5.521

Paz-Villagrán, V., Save, E., and Poucet, B. (2004). Independent coding of connected environments by place cells. Eur. J. Neurosci. 20, 1379-1390. doi: 10.1111/j.14609568.2004.03570.x

Petrone, A., Battaglia, F., Wang, C., Dusa, A., Su, J., Zagzag, D., et al. (2003). Receptor protein tyrosine phosphatase alpha is essential for hippocampal neuronal migration and long-term potentiation. EMBO J. 22, 4121-4131. doi: 10.1093/emboj/cdg399

Pierani, A., and Wassef, M. (2009). Cerebral cortex development: from progenitors patterning to neocortical size during evolution. Dev. Growth Differ. 51, 325-342. doi: 10.1111/j.1440-169X.2009.01095.x

Pleasure, S. J., Anderson, S., Hevner, R., Bagri, A., Marin, O., Lowenstein, D. H., et al. (2000). Cell migration from the ganglionic eminences is required for the development of hippocampal GABAergic interneurons. Neuron 28, 727-740. doi: 10.1016/S0896-6273(00)00149-5

Poirier, K., Lebrun, N., Broix, L., Tian, G., Saillour, Y., Boscheron, C., et al. (2013). Mutations in TUBG1, DYNC1H1, KIF5C and KIF2A cause malformations of cortical development and microcephaly. Nat. Genet. 45, 639-647. doi: 10.1038/ng.2613

Polleux, F., Whitford, K. L., Dijkhuizen, P. A., Vitalis, T., and Ghosh, A. (2002). Control of cortical interneuron migration by neurotrophins and PI3-kinase signaling. Development 129, 3147-3160.

Poluch, S., and Juliano, S. L. (2007). A normal radial glial scaffold is necessary for migration of interneurons during neocortical development. Glia 55, 822-830. doi: 10.1002/glia.20488 
Porter, B. E., Judkins, A. R., Clancy, R. R., Duhaime, A., Dlugos, D. J., and Golden, J. A. (2003). Dysplasia: a common finding in intractable pediatric temporal lobe epilepsy. Neurology 61, 365-368. doi: 10.1212/01.WNL.0000076487. 28227.6E

Pulsinelli, W. A., and Brierley, J. B. (1979). A new model of bilateral hemispheric ischemia in the unanesthetized rat. Stroke 10, 267-272. doi: 10.1161/01.STR.10.3.267

Rice, D. S., Sheldon, M., D’Arcangelo, G., Nakajima, K., Goldowitz, D., and Curran, T. (1998). Disabled-1 acts downstream of reelin in a signaling pathway that controls laminar organization in the mammalian brain. Development 125, 3719-3729.

Salinger, W. L., Ladrow, P., and Wheeler, C. (2003). Behavioral phenotype of the reeler mutant mouse: effects of RELN gene dosage and social isolation. Behav. Neurosci. 117, 1257-1275. doi: 10.1037/0735-7044.117.6.1257

Sapir, T., Elbaum, M., and Reiner, O. (1997). Reduction of microtubule catastrophe events by LIS1, platelet-activating factor acetylhydrolase subunit. EMBO J. 16, 6977-6984. doi: 10.1093/emboj/16.23.6977

Sasaki, S., Shionoya, A., Ishida, M., Gambello, M. J., Yingling, J., Wynshaw-Boris, A., et al. (2000). A LIS1/NUDEL/cytoplasmic dynein heavy chain complex in the developing and adult nervous system. Neuron 28, 681-696. doi: 10.1016/S08966273(00)00146-X

Sato, N., Hatakeyama, S., Shimizu, N., Hikima, A., Aoki, J., and Endo, K. (2001). MR evaluation of the hippocampus in patients with congenital malformations of the brain. AJNR Am. J. Neuroradiol. 22, 389-393.

Sebe, J. Y., Bershteyn, M., Hirotsune, S., Wynshaw-Boris, A., and Baraban, S. C. (2013). ALLN rescues an in vitro excitatory synaptic transmission deficit in Lis 1 mutant mice. J. Neurophysiol. 109, 429-436. doi: 10.1152/jn.00431.2012

Seki, T., and Rutishauser, U. (1998). Removal of polysialic acid-neural cell adhesion molecule induces aberrant mossy fiber innervation and ectopic synaptogenesis in the hippocampus. J. Neurosci. 18, 3757-3766.

Sekiguchi, M., Nowakowski, R. S., Nagato, Y., Tanaka, O., Guo, H., Madoka, M., et al. (1995). Morphological abnormalities in the hippocampus of the weaver mutant mouse. Brain Res. 696, 262-267. doi: 10.1016/0006-8993(95)00974-U

Seri, B., García-Verdugo, J. M., McEwen, B. S., and Alvarez-Buylla, A. (2001). Astrocytes give rise to new neurons in the adult mammalian hippocampus. J. Neurosci. 21, 7153-7160.

Shinohara, R., Thumkeo, D., Kamijo, H., Kaneko, N., Sawamoto, K., Watanabe, K., et al. (2012). A role for mDia, a Rho-regulated actin nucleator, in tangential migration of interneuron precursors. Nat. Neurosci. 15, 373-380, S1-S2. doi: 10.1038/nn.3020

Shu, T., Ayala, R., Nguyen, M. D., Xie, Z., Gleeson, J. G., and Tsai, L. H. (2004). Ndell operates in a common pathway with LIS1 and cytoplasmic dynein to regulate cortical neuronal positioning. Neuron 44, 263-277. doi: 10.1016/j.neuron.2004.09.030

Slomianka, L., Amrein, I., Knuesel, I., Sørensen, J. C., and Wolfer, D. P. (2011). Hippocampal pyramidal cells: the reemergence of cortical lamination. Brain Struct. Funct. 216, 301-317. doi: 10.1007/s00429-011-0322-0

Smith, D. S., Niethammer, M., Ayala, R., Zhou, Y., Gambello, M. J., WynshawBoris, A., et al. (2000). Regulation of cytoplasmic dynein behaviour and microtubule organization by mammalian Lis1. Nat. Cell Biol. 2, 767-775. doi: $10.1038 / 35041000$

Soriano, E., Cobas, A., and Fairén, A. (1986). Asynchronism in the neurogenesis of GABAergic and non-GABAergic neurons in the mouse hippocampus. Brain Res. 395, 88-92. doi: 10.1016/0165-3806(86)90134-3

Soriano, E., Cobas, A., and Fairén, A. (1989). Neurogenesis of glutamic acid decarboxylase immunoreactive cells in the hippocampus of the mouse. I: regio superior and regio inferior. J. Comp. Neurol. 281, 586-602. doi: 10.1002/cne.902810408

Stanfield, B. B., and Cowan, W. M. (1979a). The development of the hippocampus and dentate gyrus in normal and reeler mice. J. Comp. Neurol. 185, 423-459. doi: 10.1002/cne.901850303

Stanfield, B. B., and Cowan, W. M. (1979b). The morphology of the hippocampus and dentate gyrus in normal and reeler mice. J. Comp. Neurol. 185, 393-422. doi: 10.1002/cne.901850302

Stegeman, S., Jolly, L. A., Premarathne, S., Gecz, J., Richards, L. J., Mackay-Sim, A., et al. (2013). Loss of Usp9x disrupts cortical architecture, hippocampal development and TGF $\beta$-mediated axonogenesis. PLOS ONE 8:e68287. doi: 10.1371/journal.pone.0068287
Subramanian, L., Remedios, R., Shetty, A., and Tole, S. (2009). Signals from the edges: the cortical hem and antihem in telencephalic development. Semin. Cell Dev. Biol. 20, 712-718. doi: 10.1016/j.semcdb.2009.04.001

Subramanian, L., and Tole, S. (2009). Mechanisms underlying the specification, positional regulation, and function of the cortical hem. Cereb. Cortex 19 (Suppl. 1), i90-i95. doi: 10.1093/cercor/bhp031

Suto, F., Tsuboi, M., Kamiya, H., Mizuno, H., Kiyama, Y., Komai, S., et al. (2007). Interactions between plexin-A2, plexin-A4, and semaphorin 6A control laminarestricted projection of hippocampal mossy fibers. Neuron 53, 535-547. doi: 10.1016/j.neuron.2007.01.028

Tanaka, T., Serneo, F. F., Higgins, C., Gambello, M. J., Wynshaw-Boris, A., and Gleeson, J. G. (2004a). Lis1 and doublecortin function with dynein to mediate coupling of the nucleus to the centrosome in neuronal migration. J. Cell Biol. 165, 709-721. doi: 10.1083/jcb.200309025

Tanaka, T., Serneo, F. F., Tseng, H. C., Kulkarni, A. B., Tsai, L. H., and Gleeson, J. G. (2004b). Cdk5 phosphorylation of doublecortin ser297 regulates its effect on neuronal migration. Neuron 41, 215-227. doi: 10.1016/S0896-6273(03) 00852-3

Tawarayama, H., Yoshida, Y., Suto, F., Mitchell, K. J., and Fujisawa, H. (2010). Roles of semaphorin-6B and plexin-A2 in lamina-restricted projection of hippocampal mossy fibers. J. Neurosci. 30, 7049-7060. doi: 10.1523/JNEUROSCI.007310.2010

Thompson, C. L., Pathak, S. D., Jeromin, A., Ng, L. L., MacPherson, C. R., Mortrud, M. T., et al. (2008). Genomic anatomy of the hippocampus. Neuron 60, 1010-1021. doi: 10.1016/j.neuron.2008.12.008

Tole, S., Christian, C., and Grove, E. A. (1997). Early specification and autonomous development of cortical fields in the mouse hippocampus. Development 124, 4959-4970.

Tole, S., and Grove, E. A. (2001). Detailed field pattern is intrinsic to the embryonic mouse hippocampus early in neurogenesis. J. Neurosci. 21, 1580-1589.

Tricoire, L., Pelkey, K. A., Erkkila, B. E., Jeffries, B. W., Yuan, X., and McBain, C. J. (2011). A blueprint for the spatiotemporal origins of mouse hippocampal interneuron diversity. J. Neurosci. 31, 10948-10970. doi: 10.1523/JNEUROSCI.0323-11.2011

Trommsdorff, M., Gotthardt, M., Hiesberger, T., Shelton, J., Stockinger, W., Nimpf, J., et al. (1999). Reeler/Disabled-like disruption of neuronal migration in knockout mice lacking the VLDL receptor and ApoE receptor 2. Cell 97, 689-701. doi: 10.1016/S0092-8674(00)80782-5

Tueting, P., Costa, E., Dwivedi, Y., Guidotti, A., Impagnatiello, F., Manev, R., et al. (1999). The phenotypic characteristics of heterozygous reeler mouse. Neuroreport 10, 1329-1334. doi: 10.1097/00001756-199904260-00032

Tueting, P., Doueiri, M. S., Guidotti, A., Davis, J. M., and Costa, E. (2006). Reelin down-regulation in mice and psychosis endophenotypes. Neurosci. Biobehav. Rev. 30, 1065-1077. doi: 10.1016/j.neubiorev.2006.04.001

Valdés-Sánchez, L., Escámez, T., Echevarria, D., Ballesta, J. J., Tabarés-Seisdedos, R., Reiner, O., et al. (2007). Postnatal alterations of the inhibitory synaptic responses recorded from cortical pyramidal neurons in the Lis1/sLis1 mutant mouse. Mol. Cell. Neurosci. 35, 220-229. doi: 10.1016/j.mcn.2007.02.017

Wang, Y., and Baraban, S. C. (2007). Granule cell dispersion and aberrant neurogenesis in the adult hippocampus of an LIS1 mutant mouse. Dev. Neurosci. 29, 91-98. doi: 10.1159/000096214

Wang, Y., and Baraban, S. C. (2008). Aberrant dentate gyrus cytoarchitecture and fiber lamination in Lisl mutant mice. Hippocampus 18, 758-765. doi: 10.1002/hipo.20434

Watanabe, Y., Gould, E., and McEwen, B. S. (1992). Stress induces atrophy of apical dendrites of hippocampal CA3 pyramidal neurons. Brain Res. 588, 341-345. doi: 10.1016/0006-8993(92)91597-8

Weiss, K. H., Johanssen, C., Tielsch, A., Herz, J., Deller, T., Frotscher, M., et al. (2003). Malformation of the radial glial scaffold in the dentate gyrus of reeler mice, scrambler mice, and ApoER2/VLDLR-deficient mice. J. Comp. Neurol. 460, 56-65. doi: 10.1002/cne.10644

Wenzel, H. J., Robbins, C. A., Tsai, L. H., and Schwartzkroin, P. A. (2001). Abnormal morphological and functional organization of the hippocampus in a p35 mutant model of cortical dysplasia associated with spontaneous seizures. J. Neurosci. 21, 983-998.

Williams, M. E., Wilke, S. A., Daggett, A., Davis, E., Otto, S., Ravi, D., et al. (2011). Cadherin-9 regulates synapse-specific differentiation in the developing hippocampus. Neuron 71, 640-655. doi: 10.1016/j.neuron.2011.06.019 
Woolley, C. S., Gould, E., and McEwen, B. S. (1990). Exposure to excess glucocorticoids alters dendritic morphology of adult hippocampal pyramidal neurons. Brain Res. 531, 225-231. doi: 10.1016/0006-8993(90)90778-A

Xie, Z., Sanada, K., Samuels, B. A., Shih, H., and Tsai, L. H. (2003). Serine 732 phosphorylation of FAK by Cdk5 is important for microtubule organization, nuclear movement, and neuronal migration. Cell 114, 469-482. doi: 10.1016/S0092-8674(03)00605-6

$\mathrm{Xu}$, N. J., and Henkemeyer, M. (2009). Ephrin-B3 reverse signaling through Grb4 and cytoskeletal regulators mediates axon pruning. Nat. Neurosci. 12, 268-276. doi: 10.1038/nn.2254

Yamada, M., Yoshida, Y., Mori, D., Takitoh, T., Kengaku, M., Umeshima, H., et al. (2009). Inhibition of calpain increases LIS1 expression and partially rescues in vivo phenotypes in a mouse model of lissencephaly. Nat. Med. 15, 1202-1207. doi: $10.1038 / \mathrm{nm} .2023$

Yap, C. C., Vakulenko, M., Kruczek, K., Motamedi, B., Digilio, L., Liu, J. S., et al. (2012). Doublecortin (DCX) mediates endocytosis of neurofascin independently of microtubule binding. J. Neurosci. 32, 7439-7453. doi: 10.1523/JNEUROSCI.5318-11.2012

Ye, H., Zhao, T., Tan, Y. L., Liu, J., Pallen, C. J., and Xiao, Z. C. (2011). Receptor-like protein-tyrosine phosphatase $\alpha$ enhances cell surface expression of neural adhesion molecule NB-3. J. Biol. Chem. 286, 26071-26080. doi: 10.1074/jbc.M110.214080

Zhang, G., Assadi, A. H., McNeil, R. S., Beffert, U., Wynshaw-Boris, A., Herz, J., et al. (2007). The Pafahlb complex interacts with the reelin receptor VLDLR. PLOS ONE 2:e252. doi: 10.1371/journal.pone.0000252
Zhao, S., Chai, X., Förster, E., and Frotscher, M. (2004). Reelin is a positional signal for the lamination of dentate granule cells. Development 131, 5117-5125. doi: 10.1242/dev.01387

Zola-Morgan, S., Squire, L. R., and Amaral, D. G. (1986). Human amnesia and the medial temporal region: enduring memory impairment following a bilateral lesion limited to field CA1 of the hippocampus. J. Neurosci. 6, 2950-2967.

Conflict of Interest Statement: The authors declare that the research was conducted in the absence of any commercial or financial relationships that could be construed as a potential conflict of interest.

Received: 22 November 2013; accepted: 13 February 2014; published online: 04 March 2014.

Citation: Belvindrah R, Nosten-Bertrand $M$ and Francis $F$ (2014) Neuronal migration and its disorders affecting the CA3 region. Front. Cell. Neurosci. 8:63. doi: 10.3389/fncel.2014.00063

This article was submitted to the journal Frontiers in Cellular Neuroscience.

Copyright (C) 2014 Belvindrah, Nosten-Bertrand and Francis. This is an openaccess article distributed under the terms of the Creative Commons Attribution License (CC BY). The use, distribution or reproduction in other forums is permitted, provided the original author(s) or licensor are credited and that the original publication in this journal is cited, in accordance with accepted academic practice. No use, distribution or reproduction is permitted which does not comply with these terms. 